\title{
New sponge species from Seno Magdalena, Puyuhuapi Fjord and Jacaf Canal (Chile)
}

\author{
Marco BERTOLINO ${ }^{1}$, Gabriele COSTA ${ }^{2, *}$, Giorgio BAVESTRELLO ${ }^{3}$, \\ Maurizio PANSINI ${ }^{4} \&$ Giovanni DANERI ${ }^{5}$ \\ ${ }^{1,2,3,4}$ Dipartimento di Scienze della Terra dell'Ambiente e della Vita (DISTAV), \\ Università degli Studi di Genova, Corso Europa, 26 - 16132 Genova, Italy. \\ ${ }^{5}$ Centro de Investigación en Ecosistemas de la Patagonia (CIEP), Moraleda 16 Coyhaique, Chile. \\ ${ }^{5}$ Programa COPAS Sur Austral Universidad de Concepción, Barros Arana, Concepción, Chile. \\ *Corresponding author: gabrielec1987@gmail.com \\ ${ }^{1}$ Email: marco.bertolino@unige.it \\ ${ }^{3}$ Email: giorgio.bavestrello@unige.it \\ ${ }^{4}$ Email: pansisml@gmail.com \\ 5mail: gdaneri@ciep.cl

\footnotetext{
${ }^{1}$ urn:1sid:zoobank.org:author:71370556-B858-471C-B544-5641E2243080

${ }^{2}$ urn:1sid:zoobank.org:author:9712037F-157D-477D-AA5E-7111C26CAE1D

${ }^{3}$ urn:lsid:zoobank.org:author:4D585539-D4B7-4EB1-ABAD-629D9A547C9E

${ }^{4}$ urn:1sid:zoobank.org:author:7F4DA865-D72F-45FA-ABC5-81187748E6BF

${ }^{5}$ urn:1sid:zoobank.org:author:C4E24C36-8D7E-44B2-B0C8-4BB56A4B7A2D
}

Marco Bertolino and Gabriele Costa equally contributed to the paper and are first co-authors.

\begin{abstract}
Until now, only 177 species of sponges (Porifera) have been reported for Chilean coastal waters. Here we describe recent scuba diving surveys undertaken to improve our knowledge of the diversity of the sponge fauna of the Seno Magdalena, Puyuhuapi Fjord and Jacaf Canal in Chilean Patagonia. Despite these relatively harsh environments, our study yielded 23 species of Demospongiae, nine of which are new to science and described here: Hymerabdia imperfecta Bertolino, Costa \& Pansini sp. nov., Axinella cylindrica Bertolino, Costa \& Pansini sp. nov., Axinella coronata Bertolino, Costa \& Pansini sp. nov., Biemna aurantiaca Bertolino, Costa \& Pansini sp. nov., Biemna erecta Bertolino, Costa \& Pansini sp. nov., Biemna typica Bertolino, Costa \& Pansini sp. nov., Scopalina cribrosa Bertolino, Costa \& Pansini sp. nov., Rhizaxinella strongylata Bertolino, Costa \& Pansini sp. nov. and Darwinella pronzatoi Bertolino, Costa \& Pansini sp. nov. One species, Hymedesmia (Stylopus) lissostyla (Bergquist \& Fromont, 1988), is reported for the first time for Chile.
\end{abstract}

Keywords. Chilean fjords, Porifera, taxonomy, benthos.

Bertolino M., Costa G., Bavestrello G., Pansini M. \& Daneri G. 2020. New sponge species from Seno Magdalena, Puyuhuapi Fjord and Jacaf Canal (Chile). European Journal of Taxonomy 715: 1-49. https://doi.org/10.5852/ejt.2020.715 


\section{Introduction}

The southern tip of South America is of particular interest for ecological and biogeographic studies of marine organisms. The relative proximity of Antarctica makes this subantarctic coast a transitional zone between South America, Antarctica and the temperate Pacific area (Escribano et al. 2003).

The subantarctic inner shelf of southern Chile $\left(41-55^{\circ} \mathrm{S}\right)$ is characterized by a complex system of fjords, channels, gulf, estuaries and bays, each affected by local physical processes that strongly modulate biological productivity (Iriarte et al. 2014). Patagonian fjords are influenced by saline subantarctic surface waters and freshwater input from the continent; these waters interact to form modified subantarctic waters characterized by sharp vertical and horizontal salinity gradients (Iriarte et al. 2014 and references therein). These fjords can, therefore, be considered transitional marine systems where marked contrasts in marine biodiversity and distribution can be observed (Escribano et al. 2003).

The fjords of Chilean Patagonia cover an area of nearly $240000 \mathrm{~km}^{2}$ in one of the least densely populated areas of the country (1-8 inhabitants per $10 \mathrm{~km}^{2}$ ) (Pantoja et al. 2011). In the last three decades, however, the influence of anthropogenic activities on these mostly pristine terrestrial and aquatic ecosystems has increased. Exploitation of the natural resources of the region (fisheries, tourism) and the expansion of commercial salmon and mussel farming (Pantoja et al. 2011) are increasing the pressure on these fragile fjord ecosystems, and they now require enhanced scientific surveillance and protection.

The coastal waters of Chilean Patagonia host more than 1700 species of benthic animals (Häussermann \& Försterra 2009). The biodiversity of filter-feeding organisms is of particular interest given the high levels of primary productivity and complex physico-chemical processes occurring in these ecosystems. For example, filter-feeding cnidarians (such as hydrozoans and anthozoans) have been extensively studied in Chilean fjords in recent decades because of their role within the benthic community and subsequent ecological importance (Försterra \& Häussermann 2003; Häussermann 2006; Häussermann \& Försterra 2007a, 2007b; Sinniger \& Häussermann 2009).

On the other hand, sponges have long been studied in Patagonia since the historical campaigns of the nineteenth and twentieth centuries, such as: H.M.S. Alert (1876-1880) (Ridley 1881), H.M.S. Challenger (1873-1876) (Ridley \& Dendy 1887), S.Y. Belgica (1897-1899) (Topsent 1901) and the extensive sponge collections of Thiele (1905). Desqueyroux \& Moyano (1987), in their biogeographic analysis of the Chilean coast, listed 94 sponge species, a very limited number considering the latitudinal extent (more than $500 \mathrm{~km}$ ) and intricate morphology of the Chilean coast (Hajdu \& Desqueyroux-Faúndez 2008). This knowledge has recently been improved by scuba diving surveys and the list of Chilean Porifera now encompasses 177 species (Carvalho et al. 2007, 2011; Esteves et al. 2007; Hajdu \& DesqueyrouxFaúndez 2008; Lee et al. 2008; Azevedo et al. 2009; Willenz et al. 2009, 2016; Lopes et al. 2011; Hajdu et al. 2006, 2013; Fernandez et al. 2016; Bertolino et al. 2019; Costa et al. 2020). However, this number remains relatively low considering the huge extent of the Patagonian coastline (Försterra 2009), suggesting that further surveys of this important benthic taxon may be fruitful.

The aim of the present work is to document the diversity of sponge fauna in Seno Magdalena, Puyuhuapi Fjord and Jacaf Canal (Chile) (Fig. 1) and thus to improve the understanding of benthic communities more generally in these coastal waters. 


\section{Material and methods}

The study area is located within the Aysen Region of northern Chilean Patagonia (Fig. 1). The study focussed on Seno Magdalena, Puyuhuapi Fjord and Jacaf Canal (Fig. 1). Puyuhuapi Fjord - located in the Chilean XI region - extends to a length of $90 \mathrm{~km}$ and a maximum width of $7 \mathrm{~km}$ (Fig. 1). The mouth of the fjord connects to the larger Moraleda Channel, which opens into the Pacific Ocean, while the head of the fjord consists of a large bay, around $2 \mathrm{~km}$ wide, close to Puyuhuapi village. Within the COPAS Sur Austral Program, one area of focus is a sampling program designated to improve our knowledge of the richness of the Porifera in this area from the qualitative point of view.

Sampling was conducted in August 2016 through scuba diving. Twelve sites were chosen with depths of sampling ranging between 5 and $30 \mathrm{~m}$. Sponges were mainly collected from rocky substrates and photographed in situ with a Canon Digital IXUS 900 Ti (Fig. 1; Table 1). The specimens were fixed in $70 \%$ ethanol and processed by standard methods for sponge identification (Rützler 1978). Taxonomic decisions were made according to the revision of Demospongiae of Morrow \& Cárdenas (2015) and the classification present in the World Porifera Database (WPD) (van Soest et al. 2020). Length and width of at least 30 spicules per type were measured for each species/specimen collected. Minimum, mean (in parentheses) and maximum values of spicule dimensions are reported. For a Scanning Electron Microscope (SEM) Vega3 TESCAN type LMU analyses, dissociated spicules and dried tissues were transferred onto stubs, and then sputter coated with gold. The type specimens of any proposed new species were entrusted to the Museo Civico di Storia Naturale G. Doria of Genoa (collection acronym MSNG). Spicule slides and the other examined specimens (paratypes) are deposited in the sponge collection of the Dipartimento di Scienze della Terra dell'Ambiente e della Vita (DISTAV), Università degli Studi di Genova. All the specimens collected during the campaign were marked by the code CILE number.

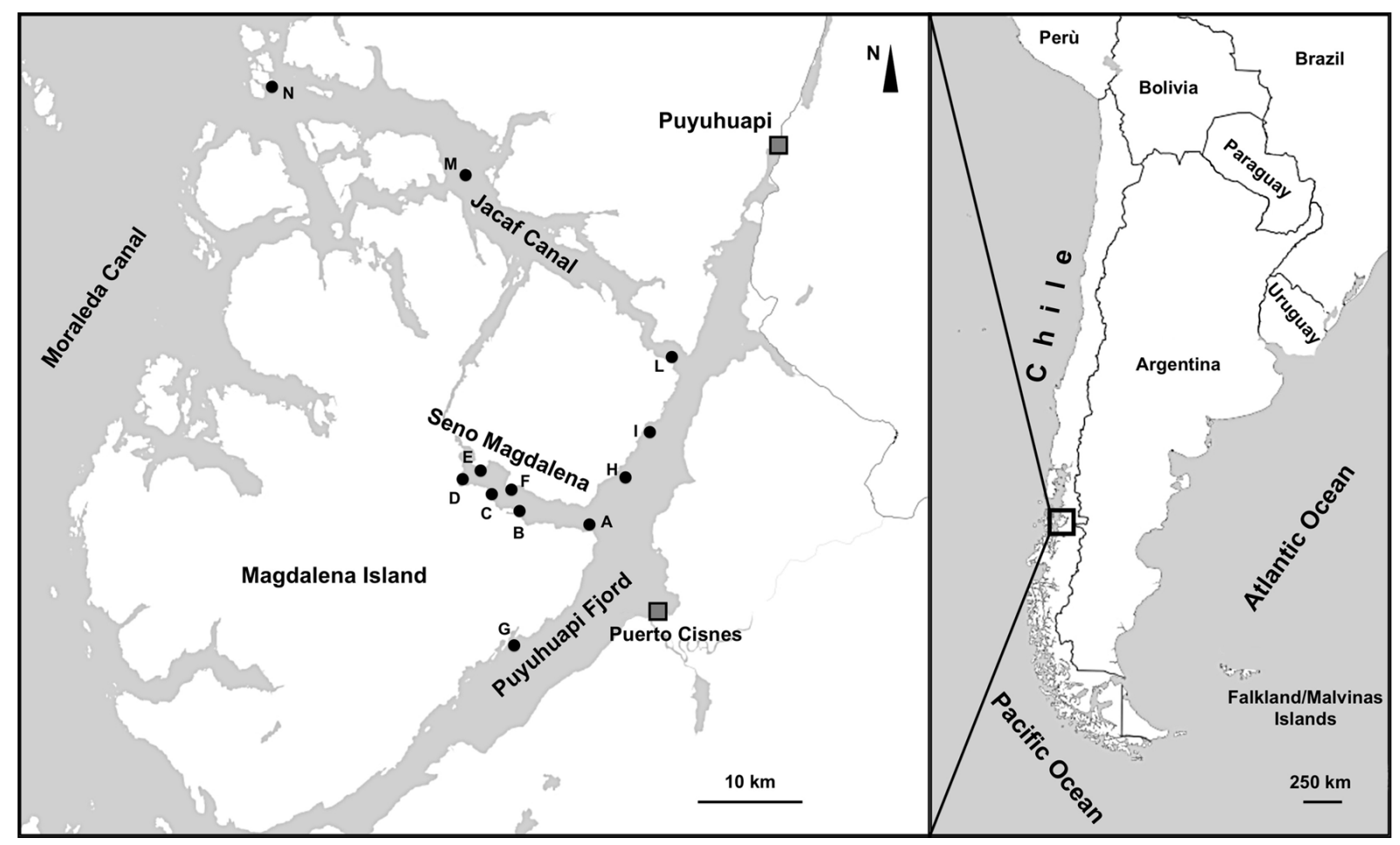

Fig. 1. Study area with twelve sampling sites (A-I, L-N). 
Table 1. Sampling sites with descripions.

\begin{tabular}{|c|c|c|c|c|}
\hline & SITES & COORDINATES & DESCRIPTIONS & DEPTH \\
\hline \multirow{7}{*}{ 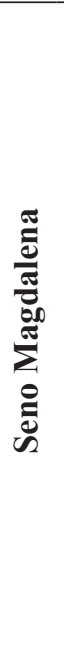 } & $\mathbf{A}$ & $\begin{array}{l}44.669581^{\circ} \mathrm{S} \\
72.798496^{\circ} \mathrm{W}\end{array}$ & $\begin{array}{l}\text { Rocky slope covered by coralline algae and } \\
\text { debris at the entrance of a channel }\end{array}$ & $0-31 \mathrm{~m}$ \\
\hline & B & $\begin{array}{l}44.650167^{\circ} \mathrm{S} \\
72.890850^{\circ} \mathrm{W}\end{array}$ & $\begin{array}{c}\text { Rocky cliff interrupted by large submarine } \\
\text { detrital heights }\end{array}$ & $0-32 \mathrm{~m}$ \\
\hline & $\mathbf{C}$ & $\begin{array}{l}44.631113^{\circ} \mathrm{S} \\
72.929130^{\circ} \mathrm{W}\end{array}$ & Rocky wall and detritus slope & $0-32 \mathrm{~m}$ \\
\hline & $\mathbf{D}$ & $\begin{array}{l}44.614863^{\circ} \mathrm{S} \\
72.958312^{\circ} \mathrm{W}\end{array}$ & $\begin{array}{l}\text { Vertical wall, ending at a depth of } 20 \mathrm{~m} \text { on a } \\
\text { rocky bottom that slopes down to } 32 \mathrm{~m}\end{array}$ & $0-32 \mathrm{~m}$ \\
\hline & $\begin{array}{c}\text { E } \\
\text { (Punta Tabla) }\end{array}$ & $\begin{array}{l}44.613885^{\circ} \mathrm{S} \\
72.941490^{\circ} \mathrm{W}\end{array}$ & Rocky cliff & $0-35 \mathrm{~m}$ \\
\hline & $\begin{array}{c}\text { F } \\
\text { (Punta Angostura) }\end{array}$ & $\begin{array}{l}44.631235^{\circ} \mathrm{S} \\
72.904239^{\circ} \mathrm{W}\end{array}$ & Rocky cliff and debris slope & $0-32 \mathrm{~m}$ \\
\hline & G & $\begin{array}{l}44.763254^{\circ} \mathrm{S} \\
72.891581^{\circ} \mathrm{W}\end{array}$ & $\begin{array}{l}\text { South side of a rocky slope covered by } \\
\text { coralline algae and debris }\end{array}$ & $0-20 \mathrm{~m}$ \\
\hline \multirow{5}{*}{ 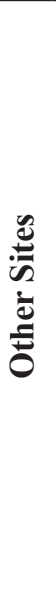 } & $\begin{array}{c}\text { H } \\
\text { (Bouy W) }\end{array}$ & $\begin{array}{l}44.609000^{\circ} \mathrm{S} \\
72.757667^{\circ} \mathrm{W}\end{array}$ & Vertical rocky wall with debris slope & $0-30 \mathrm{~m}$ \\
\hline & $\begin{array}{c}\text { I } \\
\text { (Bouy W) }\end{array}$ & $\begin{array}{l}44.580650^{\circ} \mathrm{S} \\
72.730850^{\circ} \mathrm{W}\end{array}$ & Vertical rocky wall with debris slope & $0-30 \mathrm{~m}$ \\
\hline & $\begin{array}{l}\quad L \\
\text { Canal Jacaf } \\
\text { (Ite Carlos) }\end{array}$ & $\begin{array}{l}44.522694^{\circ} \mathrm{S} \\
72.693722^{\circ} \mathrm{W}\end{array}$ & $\begin{array}{l}\text { Rocky wall ending on a debris bottom inside } \\
\text { the channel located between the coast and the } \\
\text { island }\end{array}$ & $0-24 \mathrm{~m}$ \\
\hline & $\begin{array}{c}\text { M } \\
\text { Canal Jacaf }\end{array}$ & $\begin{array}{l}44.345000^{\circ} \mathrm{S} \\
72.951528^{\circ} \mathrm{W}\end{array}$ & $\begin{array}{l}\text { Rocky walls ending on a debris bottom inside } \\
\text { the channel located between the coast and the } \\
\text { island }\end{array}$ & $0-24 \mathrm{~m}$ \\
\hline & $\begin{array}{c}\mathrm{N} \\
\text { Canal Jacaf }\end{array}$ & $\begin{array}{l}44.271194^{\circ} \mathrm{S} \\
73.209222^{\circ} \mathrm{W}\end{array}$ & $\begin{array}{l}\text { Rocky walls ending on a debris bottom inside } \\
\text { the channel located between the coast and the } \\
\text { island }\end{array}$ & $0-24 \mathrm{~m}$ \\
\hline
\end{tabular}

\section{Results}

In total, the survey collected 44 specimens of demosponges belonging to 23 species (Table 2), with nine species that are new to science: Hymerhabdia imperfecta Bertolino, Costa \& Pansini sp. nov., Axinella cylindrica Bertolino, Costa \& Pansini sp. nov., A. coronata Bertolino, Costa \& Pansini sp. nov., Biemna aurantiaca Bertolino, Costa \& Pansini sp. nov., B. erecta Bertolino, Costa \& Pansini sp. nov., B. typica Bertolino, Costa \& Pansini sp. nov., Scopalina cribrosa Bertolino, Costa \& Pansini sp. nov., Rhizaxinella strongylata Bertolino, Costa \& Pansini sp. nov., Darwinella pronzatoi Bertolino, Costa \& Pansini sp. nov. One species, Hymedesmia (Stylopus) lissostyla (Bergquist \& Fromont, 1988) was reported for the first time in Chile. Axinella cylindrica was the species with the largest number of specimens (4) and was recorded at four sites (Table 2). The site with the largest number of collected specimens (14) and species was site E in Seno Magdalena. The geographical distribution of the collected and described species is shown in Table 2. 


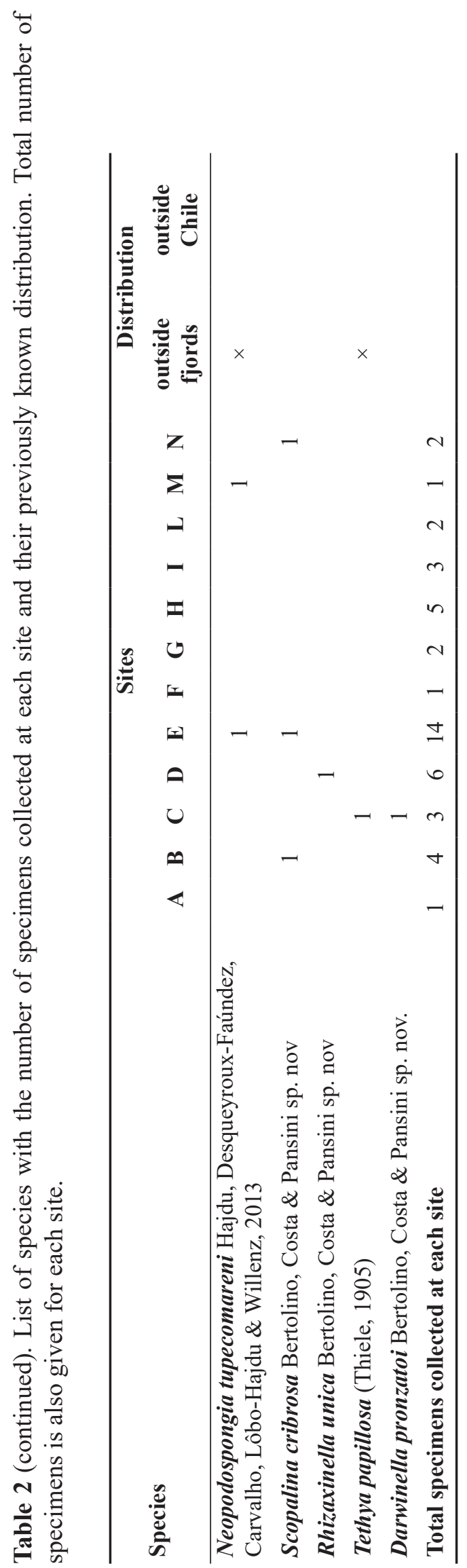




\title{
Results
}

\author{
Class Desmospongiae Sollas, 1885 \\ Subclass Heteroscleromorpha Cárdenas, Pérez \& Boury-Esnault, 2012 \\ Order Agelasida Hartman, 1980 \\ Family Hymerhabdiidae Morrow, Picton, Erpenbeck, Boury-Esnault, Maggs \& Allcock, 2012 \\ Genus Hymerhabdia Topsent, 1892 \\ Hymerhabdia imperfecta Bertolino, Costa \& Pansini sp. nov. \\ urn:1sid:zoobank.org:act:FF9FC2BD-D935-4B83-B345-228C74D457B2
}

Fig. 2; Table 3

\section{Etymology}

The new species is named after the presence of imperfect rhabdostyles.

\section{Type material}

\section{Holotype}

CHILE - Puerto Cisnes • Seno Magdalena E; 44.613885 S, 72.94149 ${ }^{\circ} \mathrm{W}$; depth $30 \mathrm{~m}$; 5-10 Aug. 2016; Marco Bertolino leg.; on a rocky cliff by scuba diving; CILE 63; MSGN 60889.

\section{Paratype}

CHILE - Puerto Cisnes - 1 specimen; Seno Magdalena F (Punta Angostura); 44.6312,35 ${ }^{\circ}$ S, 72.904239 ${ }^{\circ}$ W; depth 25 m; 5-10 Aug. 2016; Marco Bertolino leg.; on a rocky cliff by scuba diving; CILE 43; DISTAV.

\section{Description}

HaBitus. Encrusting, $5 \mathrm{~mm}$ thick and $5 \mathrm{~cm}$ long (Fig. 2A). Surface rugose and hispid, with visible canals converging towards oscules. Colour in life bright orange (Fig. 2A). Consistency of live specimens friable.

Skeleton. Choanosomal skeleton formed by bundles of long styles and tylostyles with heads embedded in basal layer of rhabdostyles and sinuous sub-tylostyles.

Sicules. Megascleres: Smooth styles, long and thin, sometimes with modified heads (Fig. 2B), 800(888.33)-1000 $\mu \mathrm{m}$ long and 5-(7.16)-10 $\mu \mathrm{m}$ thick. Smooth tylostyles 410-(552.5)-700 $\mu \mathrm{m}$ long and 15-(18.9)-25 $\mu \mathrm{m}$ thick (Fig. 2C). Rather short rhabdostyles with heads variable in shape and with pointed or round extremities (Fig. 2D), 140-(252.42)-415 $\mu \mathrm{m}$ long and 7.5-(9.75)-12.5 $\mu \mathrm{m}$ thick. Rhabdostyles often sinuous or modified into oxeas or strongyles (Fig. 2E).

\section{Habitat}

Species lives on a rocky cliff at a depth of 25-30 m; Chilean fjords.

\section{Remarks}

Out of the nine species of Hymerhabdia previously described around the world (Table 3), none have been recorded along Chilean coasts. The only species of this genus from the Southern Hemisphere is Hymerhabdia oxeata (Dendy, 1924) recorded at a depth of $183 \mathrm{~m}$ in northern New Zealand. Hymerabdia imperfecta sp. nov. differs from $H$. oxeata in having a red colour whereas in $H$. oxeata the colour is dark brown. As to spicules, $H$. oxeata has oxeas whereas the new species has tylostyles and rhabdostyles that are not present in H. oxeata. Moreover, the styles of the new species are much larger (Table 3). A comparison with the other 8 species of Hymerhabdia (from the Atlantic Ocean and the Mediterranean Sea reported in Table 3) shows remarkable differences in presence or absence of spicules (oxeas, rhabdostrongyles, toxostrongyles) and in their shape and size. 


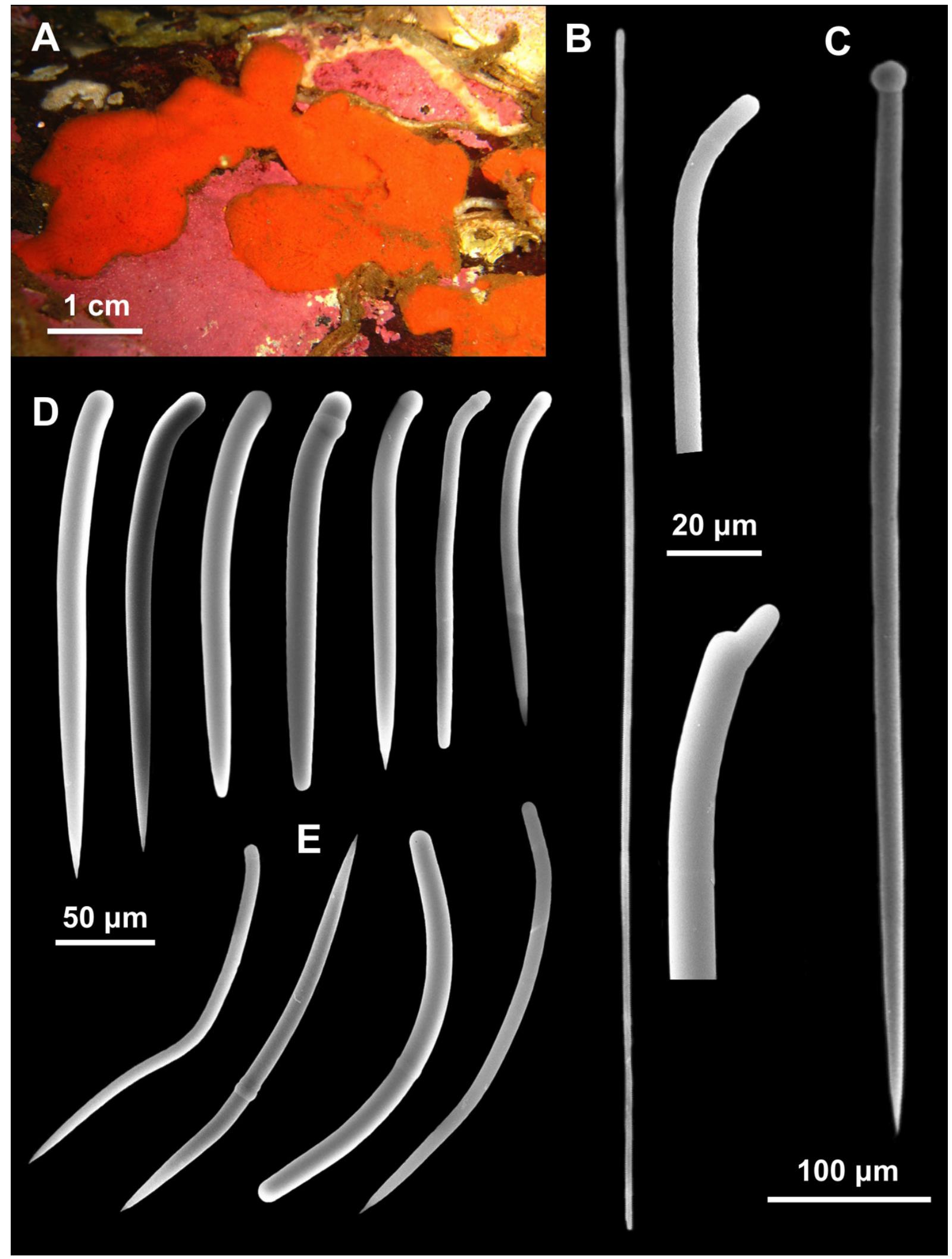

Fig. 2. Hymerhabdia imperfecta Bertolino, Costa \& Pansini sp. nov., holotype (CILE 63; MSGN 60889). A. The holotype in life. B. Smooth styles. C. Smooth thicker tylostyles. D. Rhabdostyles. E. Rhabdostyles are often sinuous or modified in oxeas or strogyles. 


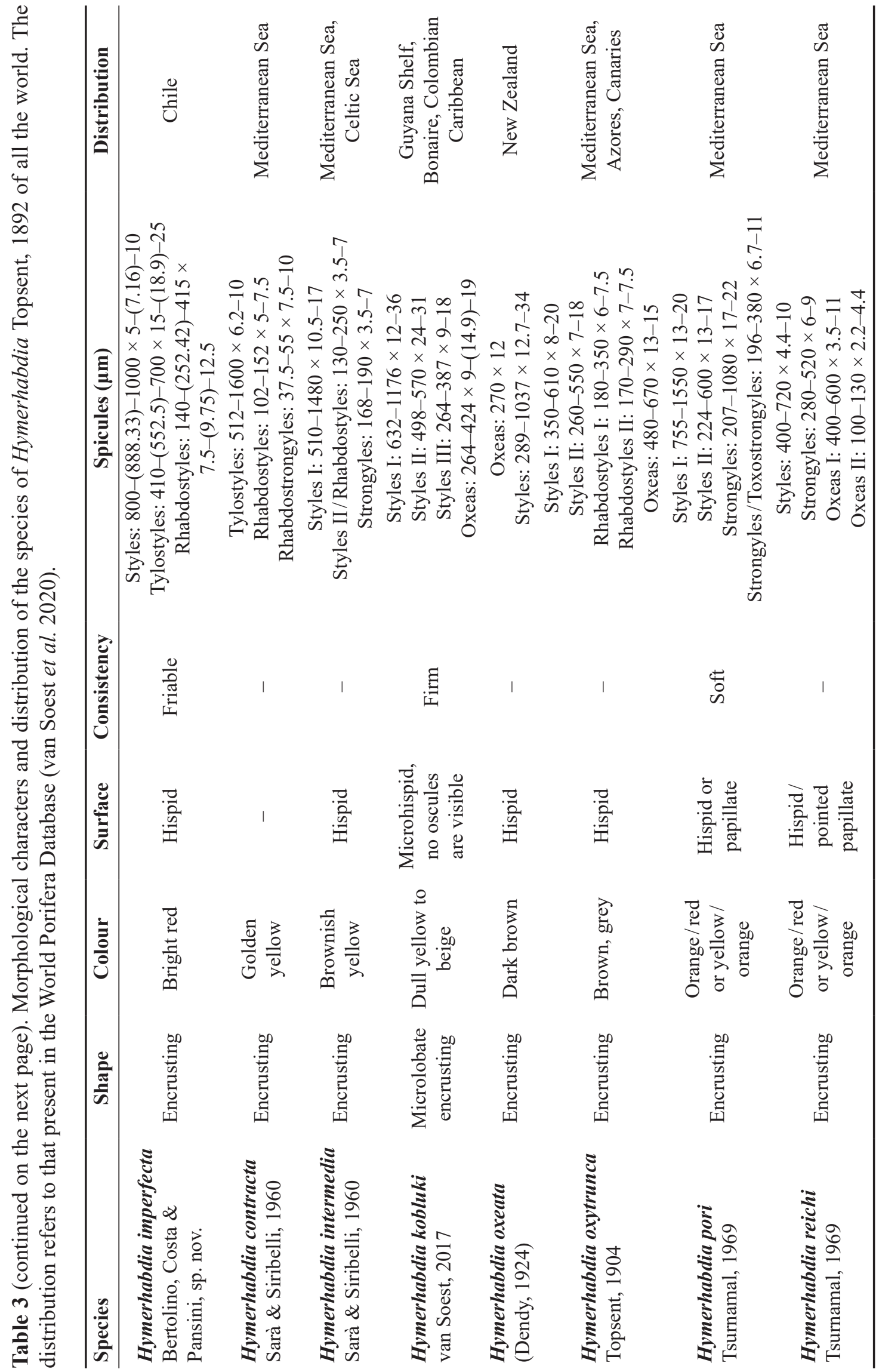




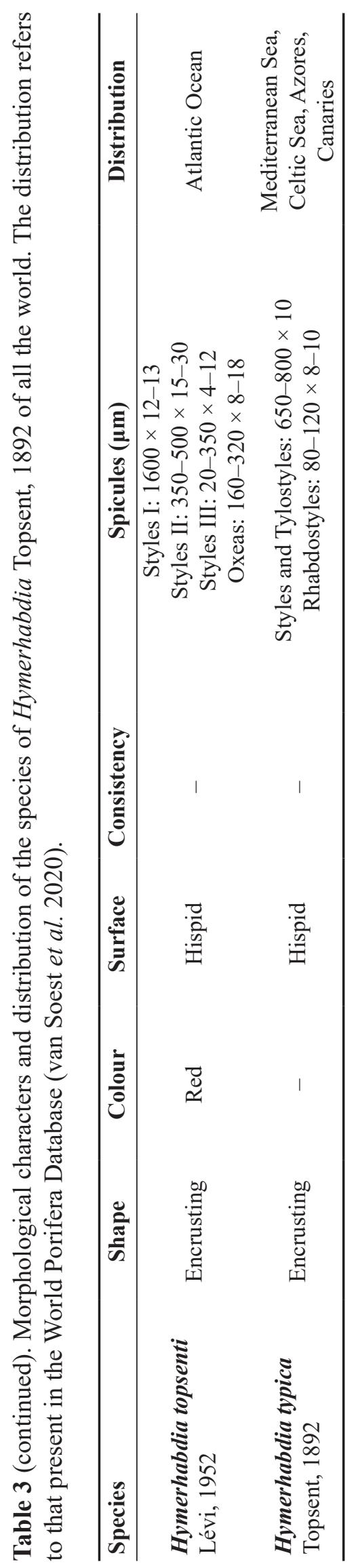


BERTOLINO M. et al., New sponge species from Chilean Fjords

Order Axinellida Lévi, 1953

Family Axinellidae Carter, 1875

Genus Axinella Schmidt, 1862

Axinella cylindrica Bertolino, Costa \& Pansini sp. nov. urn:1sid:zoobank.org:act:21616DF2-8C48-428E-8631-C6A2553E214C

Figs 3-4; Table 4

\section{Etymology}

The new species is named after the body shape.

\section{Type material}

\section{Holotype}

CHILE - Puerto Cisnes - Seno Magdalena B; $44.650167^{\circ}$ S, $72.89085^{\circ} \mathrm{W}$; depth $20 \mathrm{~m}$; 5-10 Aug. 2016; Marco Bertolino leg.; on a rocky cliff by scuba diving; CILE 1; MSGN 61493.

\section{Paratypes}

CHILE - Puerto Cisnes - 1 specimen; Seno Magdalena D; $44.614863^{\circ}$ S, $72.958312^{\circ}$ W; depth 18 m; 5-10 Aug. 2016; Marco Bertolino leg.; on a rocky bottom by scuba diving; CILE 37; DISTAV - 1 specimen; Seno Magdalena E; 44.613885 ${ }^{\circ}$ S, 72.941490 ${ }^{\circ}$ W; depth 15 m; 5-10 Aug. 2016; Marco Bertolino leg.; on a rocky cliff by scuba diving; CILE 23; DISTAV 1 specimen; Seno Magdalena D; 56.616666 S, 72.716666 ${ }^{\circ} \mathrm{W}$; depth $20 \mathrm{~m}$; 5-10 Aug. 2016; Marco Bertolino leg.; on a rocky wall by scuba diving; CILE 81; DISTAV.

\section{Description}

Habitus. All of the specimens have a regular cylindrical shape $(5-7 \mathrm{~cm}$ high, $\mathrm{ca} 1 \mathrm{~cm}$ in diameter) (Fig. 3A). Surface lightly hispid, consistence firm. Colour in life bright yellow (Fig. 3A).

SKELETON. Skeleton formed by network of thin ascending plurispicular fibres forming quadrangular meshes with abundant spongin (Fig. 3B). Choanosome differentiated in axial compressed region (Fig. 3D) and extra-axial plumoreticulate part (Fig. 3C-D). Ectosome formed by erect spicule brushes, hispidating sponge surface, supported by terminal part of choanosomal ascending fibres (Fig. 3C-D).

SPICULES. Megascleres: Styles smooth, straight or slightly curved, with regular, round heads (Fig. 4A), 700-(832.5)-960 $\mu \mathrm{m}$ long and 20-(25.2)-32.5 $\mu \mathrm{m}$ thick in holotype. Rhabdostyles smooth with pronounced basal bend (Fig. 4B), 240-(296.5)-435 $\mu \mathrm{m}$ long and 15-(17)-20 $\mu \mathrm{m}$ thick in holotype. Oxeas smooth, more or less folded, 197.5-(346)-425 $\mu \mathrm{m}$ long and 12.5-(18.7)-22.5 $\mu \mathrm{m}$ thick in holotype. The thinnest ones are almost straight or slightly flexuous (Fig. 4C). Measurements of spicule of all collected specimens (holotype and paratypes) are reported in Table 4.

\section{Habitat}

This species lives on a rocky cliff covered by coralline algae, at a depth between 15 and $20 \mathrm{~m}$.

\section{Remarks}

We have recorded two new species of the genus Axinella and have therefore chosen to make a single discussion after their description. 


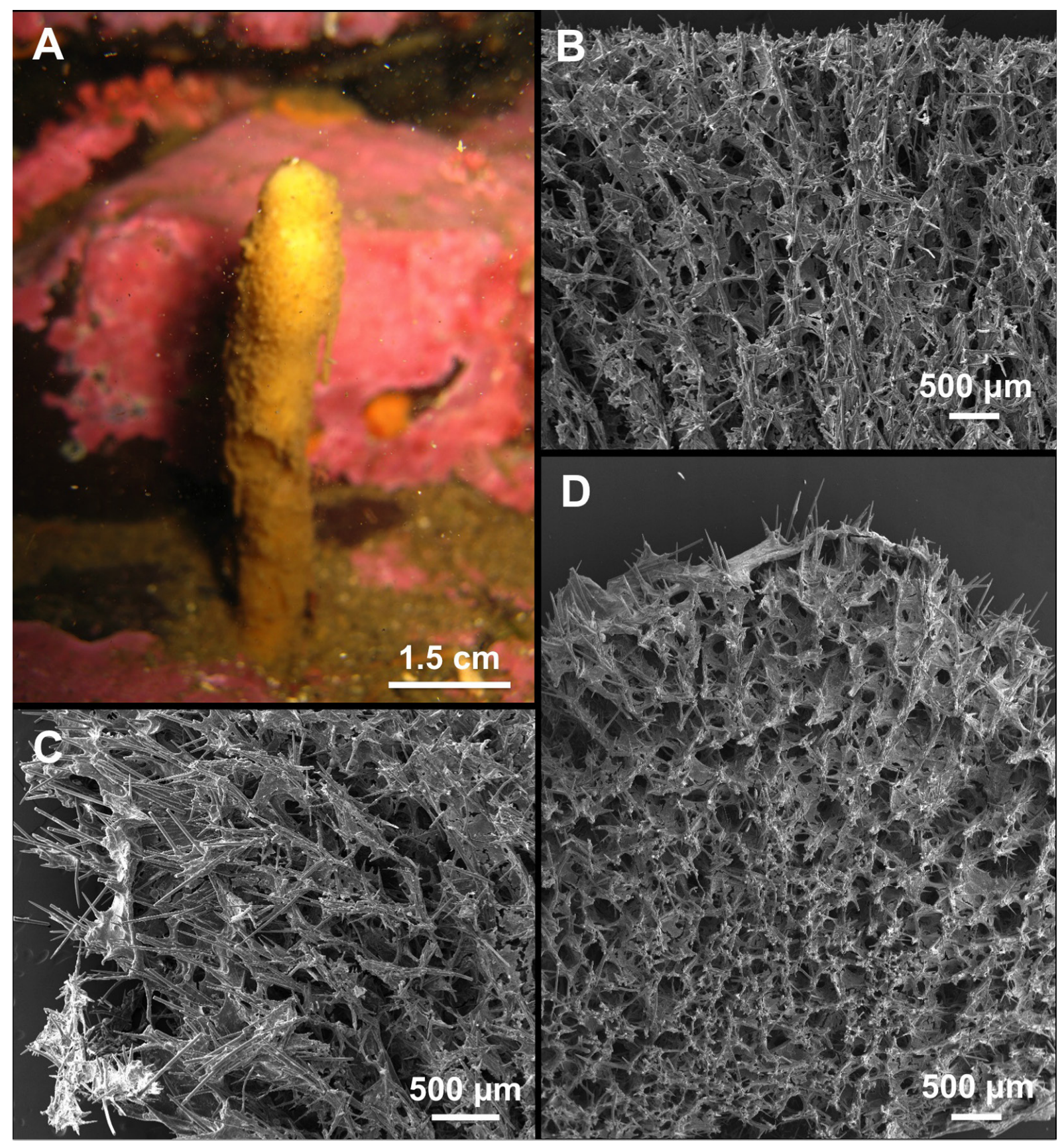

Fig. 3. Axinella cylindrica Bertolino, Costa \& Pansini sp. nov., holotype (CILE 1; MSGN 61493). A. The holotype in life. B. Skeleton formed by a network of thin ascending plurispicular fibres. C. Extraaxial pumoreticulate skeleton. D. Skeleton differentiated in two regions, axial compressed reticulated and extra-axial plumoreticulate. 


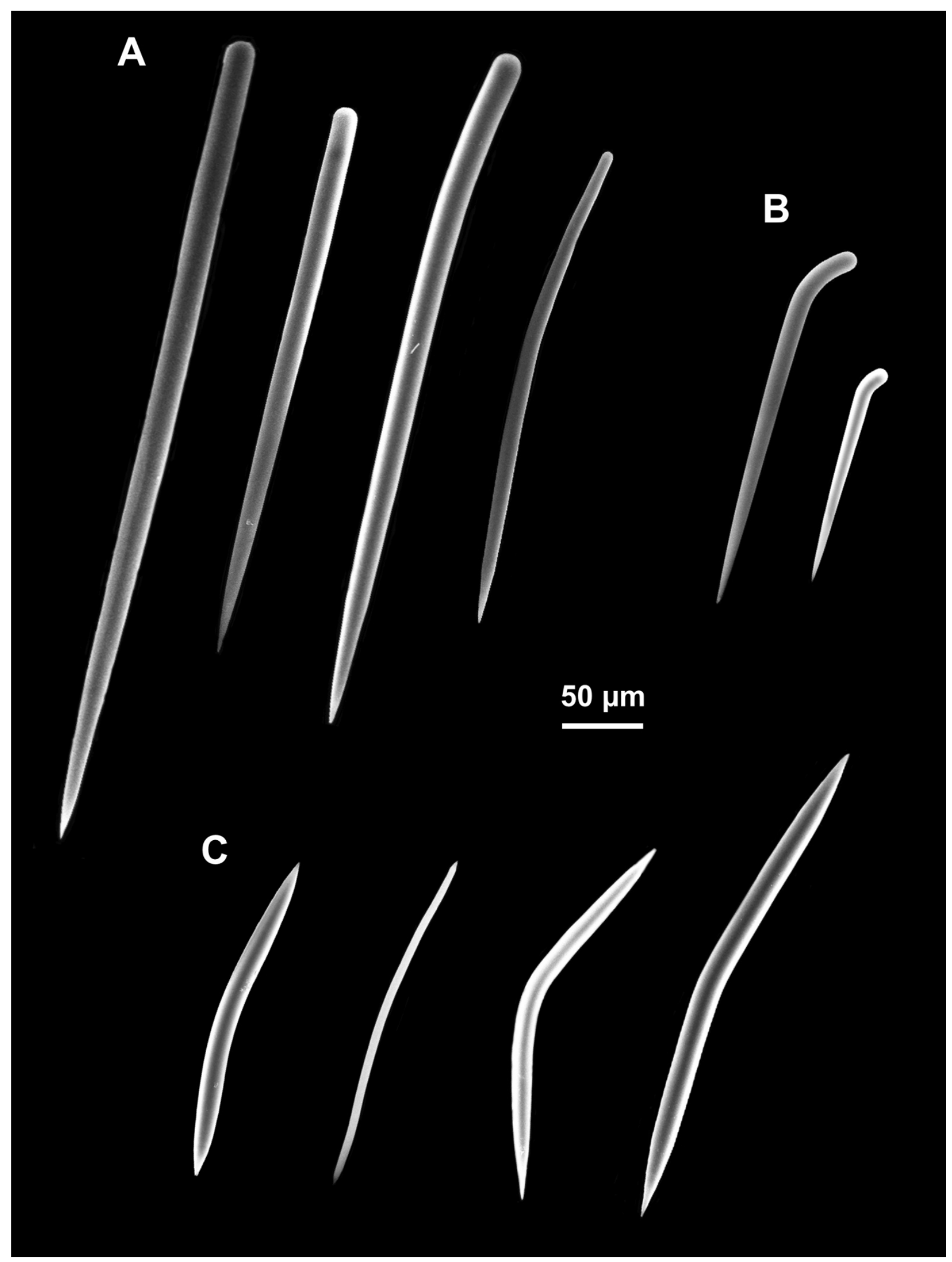

Fig. 4. Spicules of Axinella cylindrica Bertolino, Costa \& Pansini sp. nov., holotype (CILE 1; MSGN 61493). A. Smooth styles. B. Rhabdostyles. C. Oxeas. 
Table 4. Comparison of spicule dimensions (in $\mu \mathrm{m}$ ) among specimens of Axinella cylindrica Bertolino, Costa \& Pansini sp. nov.

\begin{tabular}{cccc}
\hline Specimens & Styles & Rhabdostyles & Oxeas \\
\hline CILE 1 & $700-(832.5)-960 \times$ & $240-(296.5)-435 \times$ & $197.5-(346)-425 \times$ \\
Holotype & $20-(25.2)-32.5$ & $15-(17)-20$ & $12.5-(18.7)-22.5$ \\
(MSGN 61493) & & & \\
CILE 23 & $513-(686.6)-1005 \times$ & $238-(323.5)-451 \times$ & $283-(399.5)-492 \times$ \\
& $21-(26.2)-29$ & $13-(19)-26$ & $16-(20)-29$ \\
CILE 37 & $360-(614.7)-930 \times$ & $117.5-(253.4)-390 \times$ & $182.5-(345.3)-425 \times$ \\
& $2.5-(20)-30$ & $12.5-(17.9)-22.5$ & $5-(17.9)-22.5$ \\
CILE 81 & $204-(620.6)-887 \times$ & $194-(274.4)-418 \times$ & $224-(393.2)-612 \times$ \\
& $8-(13.6)-23$ & $5-(14.3)-21$ & $10-(17.4)-26$ \\
\hline
\end{tabular}

\section{Axinella coronata Bertolino, Costa \& Pansini sp. nov. urn:lsid:zoobank.org:act:29550A2F-F048-40D5-B473-906EB62DC478}

Figs 5-6; Table 5

\section{Etymology}

The new species is named after the crown of thin styles surrounding single tylostyles.

\section{Type material}

\section{Holotype}

CHILE - Puerto Cisnes - Seno Magdalena B; $44.650167^{\circ}$ S, $72.89085^{\circ} \mathrm{W}$; depth $20 \mathrm{~m}$; 5-10 Aug. 2016; Marco Bertolino leg.; on a rocky cliff by scuba diving; CILE 22; MSGN 61494.

\section{Paratypes}

CHILE - Puerto Cisnes • 1 specimen; Seno Magdalena E (Punta Tabla); $44.613885^{\circ}$ S, $72.94149^{\circ}$ W; depth 22 m; 5-10 Aug. 2016; Marco Bertolino leg.; on a rocky cliff by scuba diving; CILE 9; DISTAV - 1 specimen; Seno Magdalena C; 44.631113 ${ }^{\circ}$ S, 72.929130 W; depth 25 m; 5-10 Aug. 2016; Marco Bertolino leg.; on a rocky wall by scuba diving; CILE 15; DISTAV.

\section{Description}

Habitus. Fan shaped sponge, $2 \mathrm{~cm}$ high, very thin ( $2 \mathrm{~mm}$ maximum), with short basal stem. Surface very hispid with tufts of macroscleres coming out from surface (Fig. 5A-B). Consistency hard but friable. Colour in life bright yellow (Fig. 5A-B).

SkELETON. Plumose, formed by multi-spicular primary tracts, radiating from axis towards surface (Fig. 5C-D), ending in single tylostyle surrounded by crown of thin styles that projects slightly through sponge surface (Fig. 5E-F).

SPICULES. Megascleres: Tylostyles slightly curved (Fig. 6A), 1300-(1962)-2200 $\mu \mathrm{m}$ long and 10(17.42)-25 $\mu \mathrm{m}$ thick. Long, smooth and thin styles, with shaft slightly thickened in distal third (Fig. 6B), $1200-(1500)-1800 \mu \mathrm{m}$ long and 2.5-(3.3)-5 $\mu \mathrm{m}$ thick. Styles to tylostyles or subtylostyles more or less bent near head as true rhabdostyles (Fig. 6C), 460-(505)-590 $\mu \mathrm{m}$ long and 10-(15.62)-20 $\mu \mathrm{m}$ thick. Thin and sinuous styles, with round heads and slightly rounded points (Fig. 6D), 460-(556.5)-600 $\mu \mathrm{m}$ long and 2.5-(3.5)-5 $\mu \mathrm{m}$ thick. 


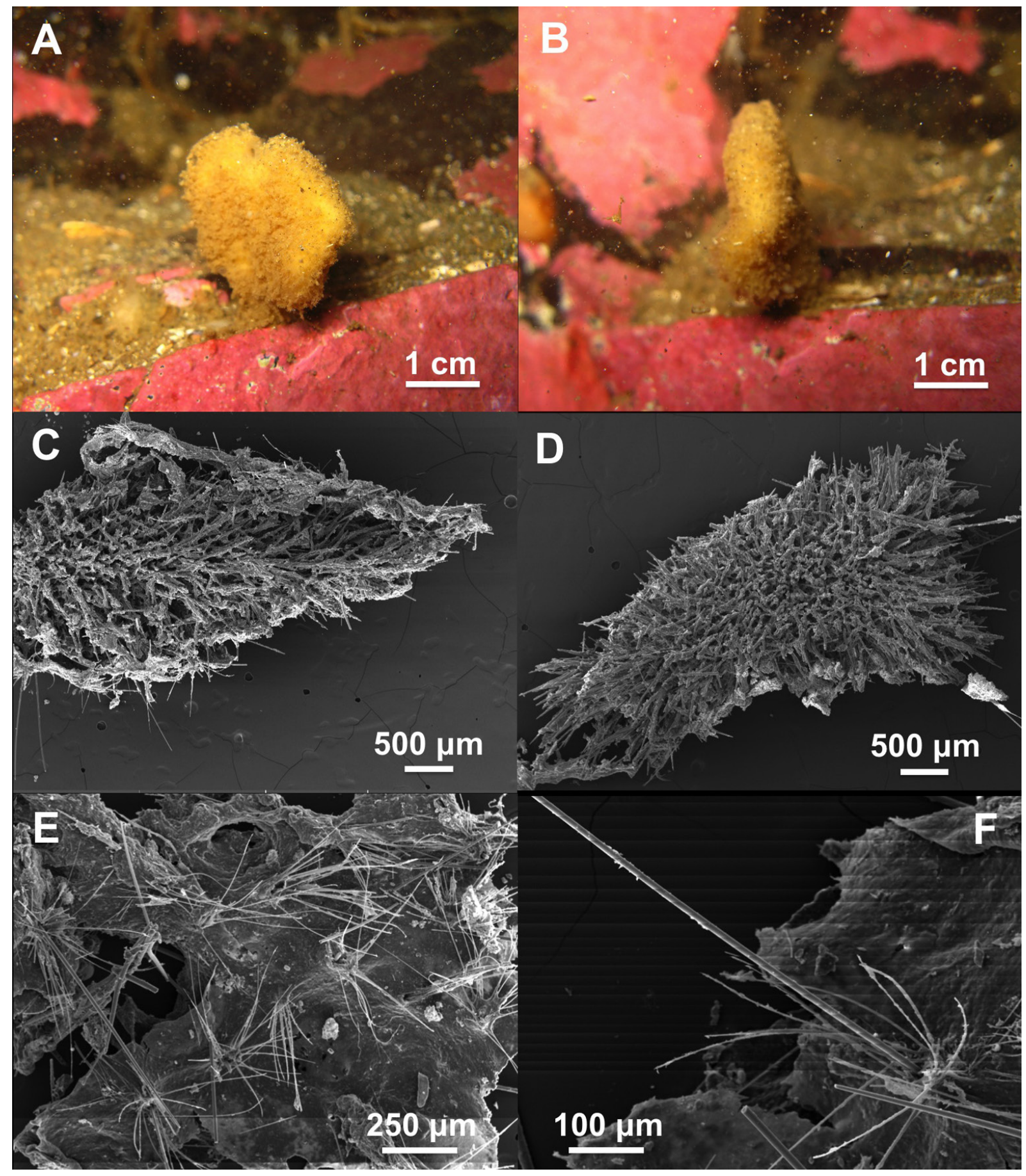

Fig. 5. Axinella coronata Bertolino, Costa \& Pansini sp. nov., holotype (CILE 22; MSGN 61494). A-B. The holotype in life. C. Plumose multispicular skeleton. D. Cross section of the skeleton. E. Ectosome. F. Magnification of a single tylostyle, surrounded by a crown of thin styles. 


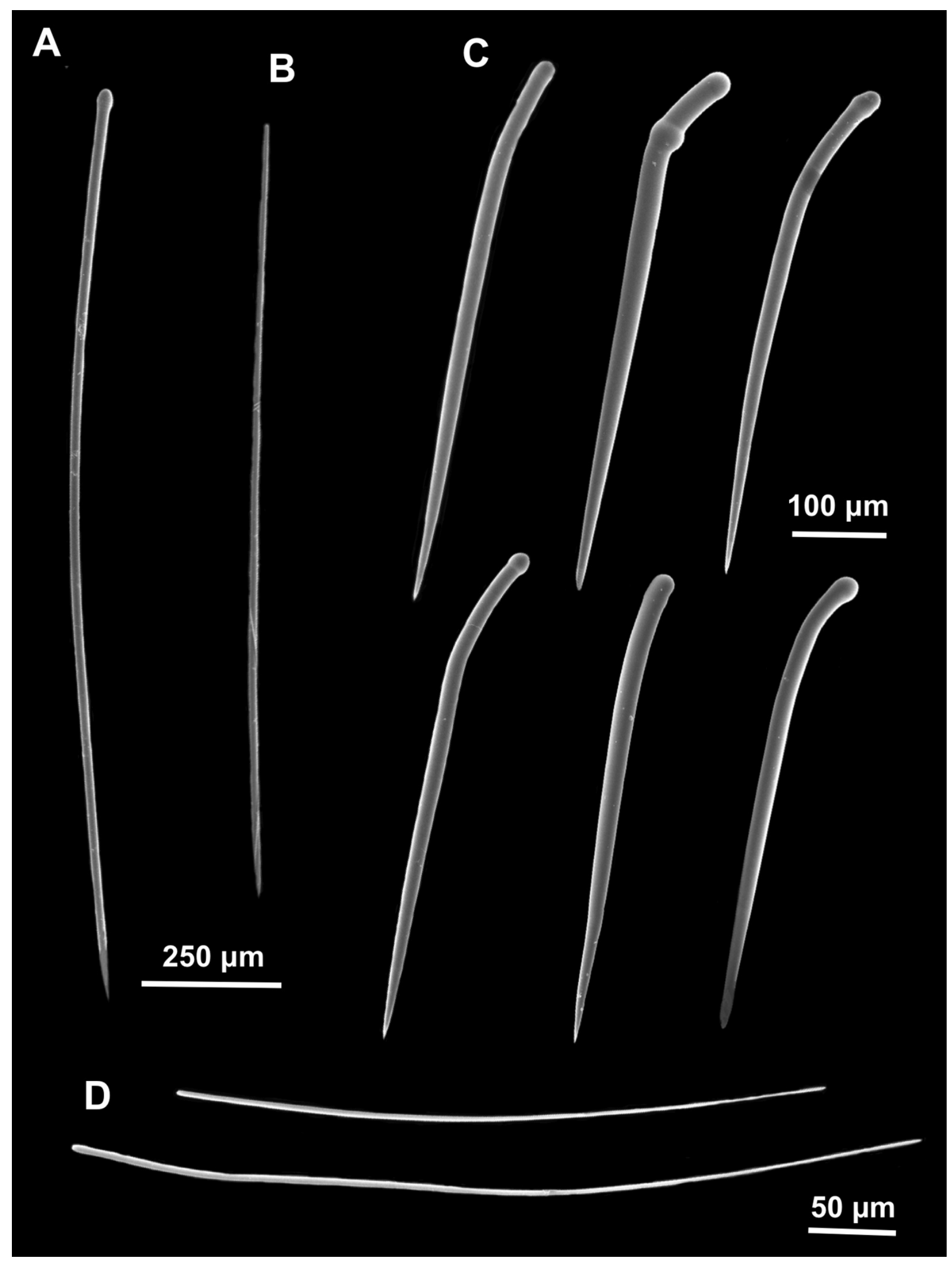

Fig. 6. Spicules of Axinella coronata Bertolino, Costa \& Pansini sp. nov., holotype (CILE 22; MSGN 61494). A. Tylostyles. B. Styles. C. Styles bend near the head similar to rhabdostyles. D. Thin and sinuous styles. 


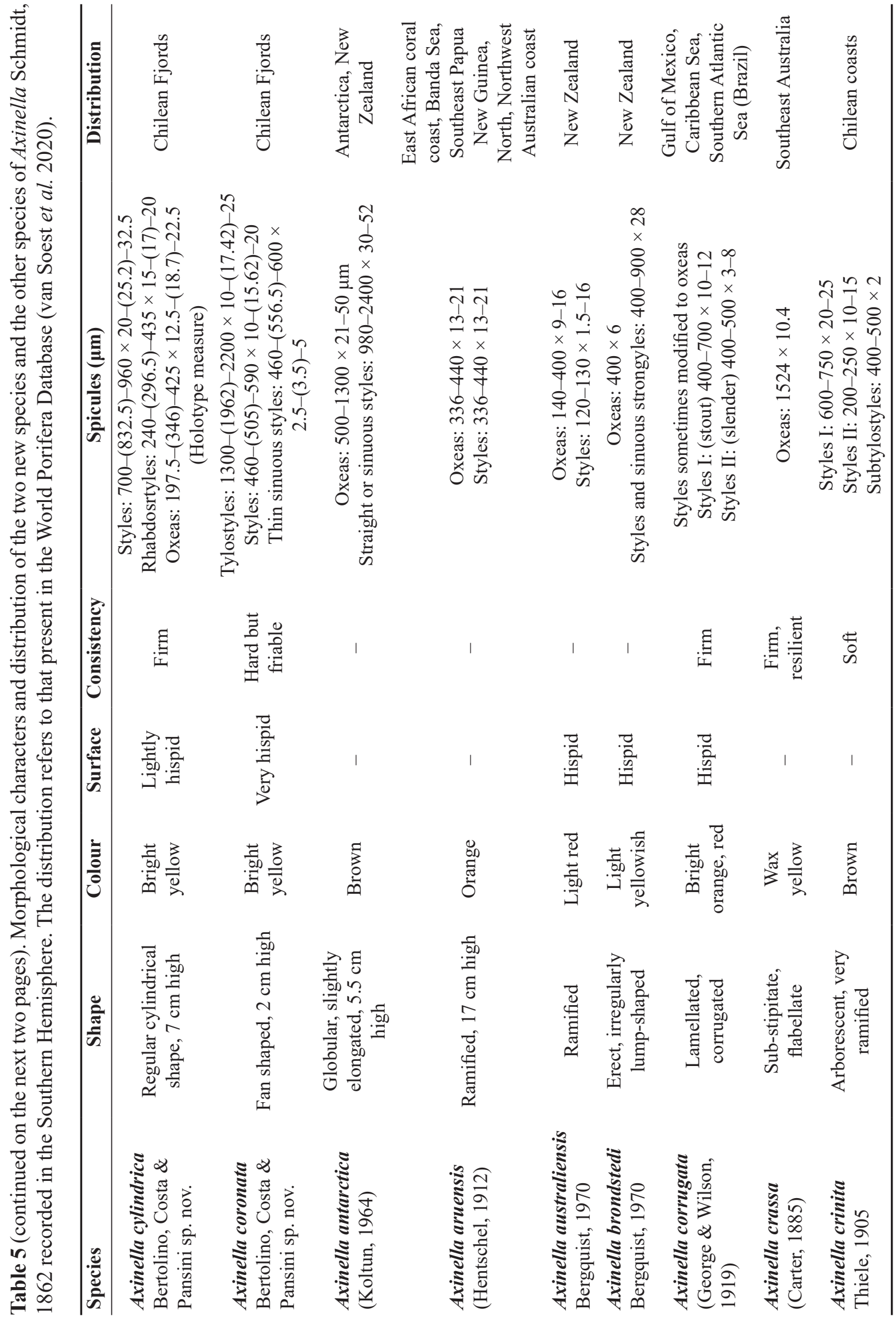


0
$\Xi$
.
0
0
0
0
0
0
0
0
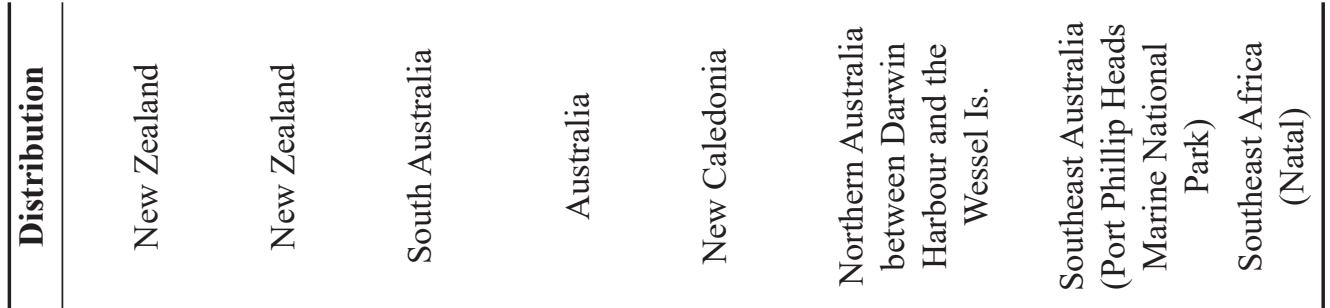

:

$\stackrel{\widetilde{2}}{\widetilde{2}}$

竎

फ्ञ

के

$\stackrel{0}{0}$

की

可

चै ส

$\stackrel{0}{ \pm}$

元

$\cdot \frac{0}{\tilde{J}}$

की

苟

范

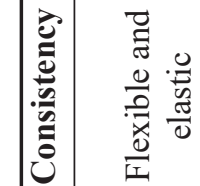

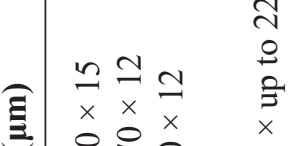

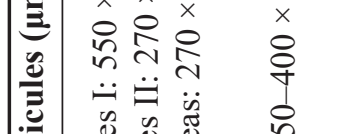

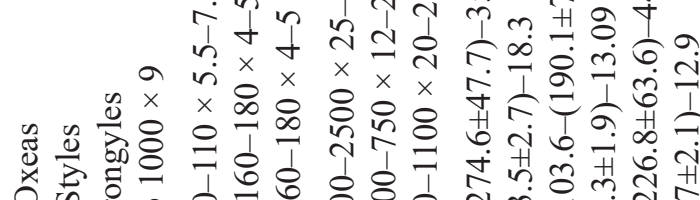

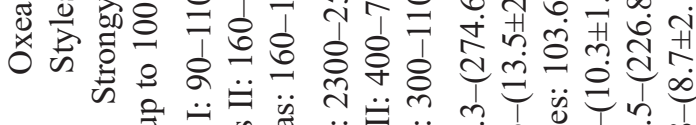

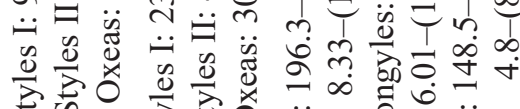

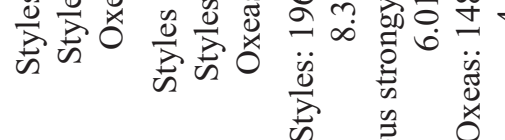

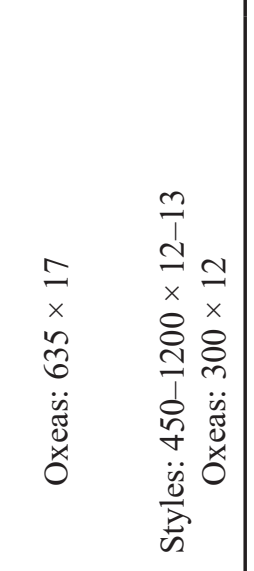

is

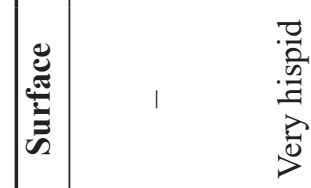

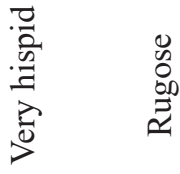

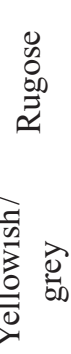

壱

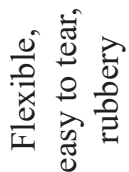

貝

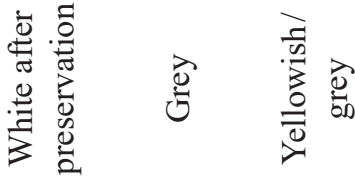

용

过

氙

is

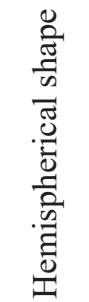

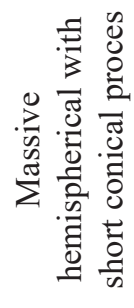

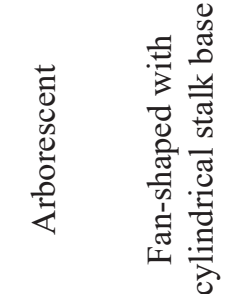

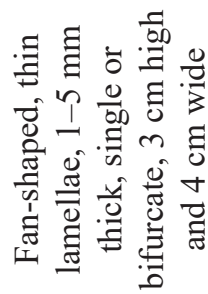

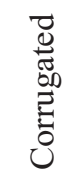

苟

름

ڤ

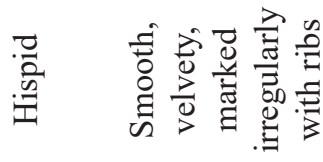

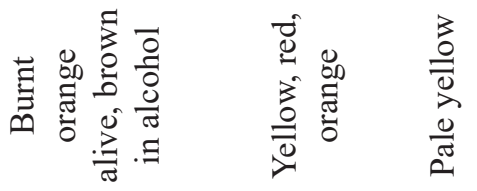

它离

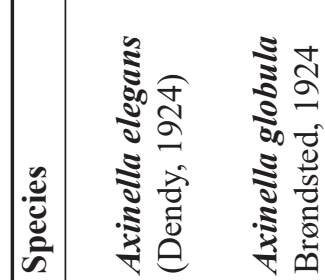

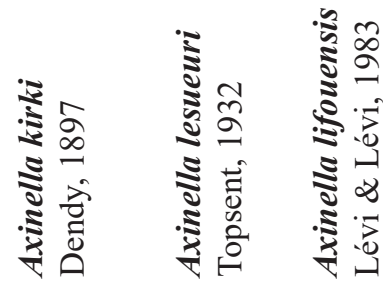

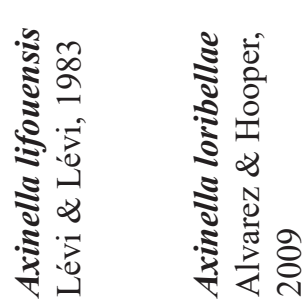

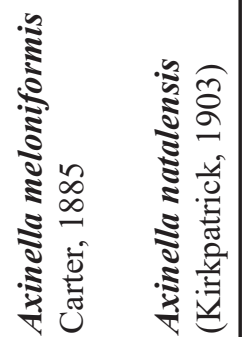




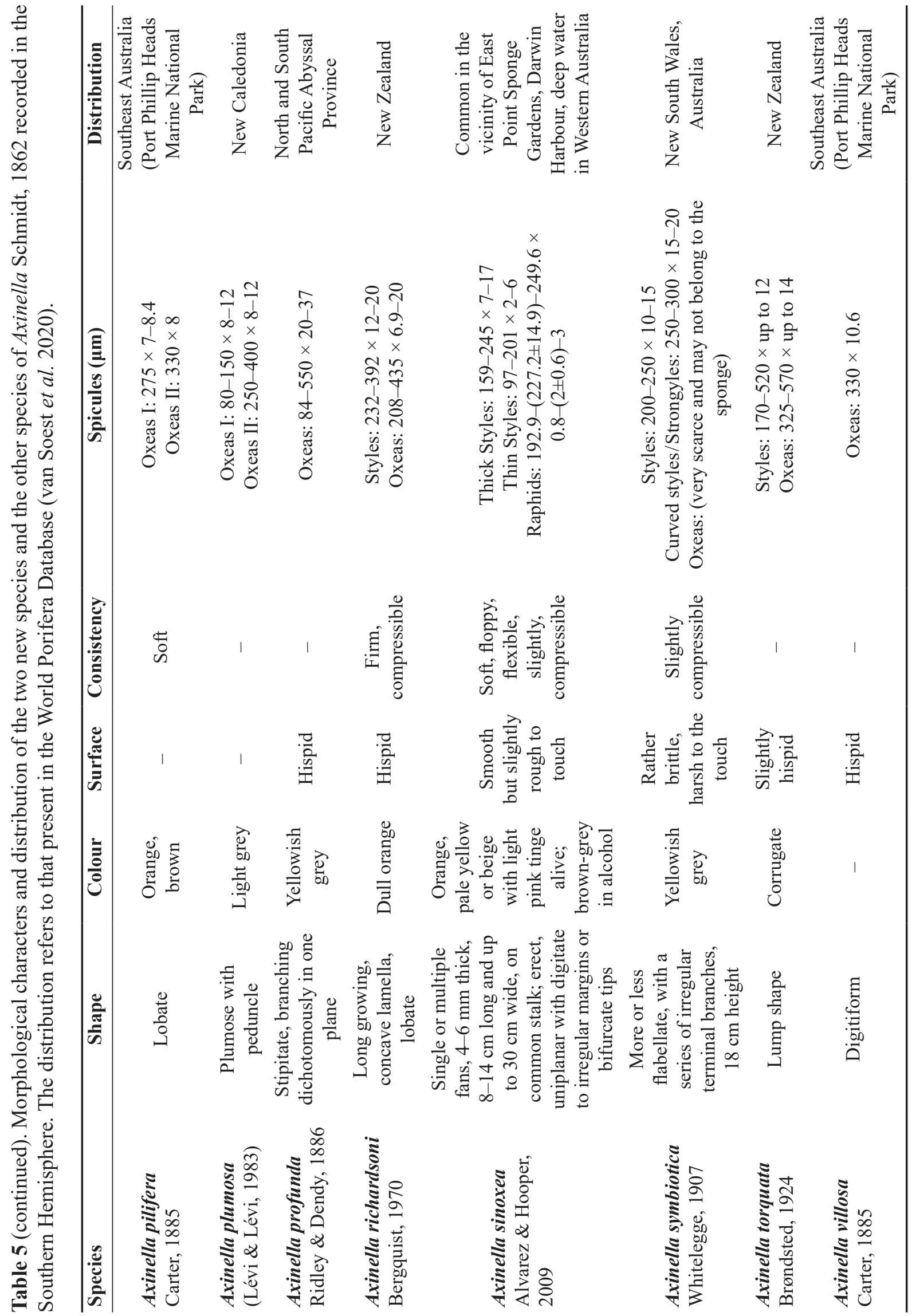




\section{Habitat}

Recorded on rocky cliffs and walls covered by coralline algae, at a depth between 20 and $25 \mathrm{~m}$.

\section{Remarks}

The attribution of $A$. cylindrica sp. nov. and A. coronata sp. nov. to the genus Axinella Schmidt, 1862 is based on the skeleton architecture characterised by a choanosomal skeleton differentiated in the axial (compressed or vaguely reticulated) and extra-axial (plumoreticulated) regions. The only species of this genus present on the Chilean coast is $A$. crinita Thiele, 1905. This species differs from the two newly described species in external shape (very ramified with cylindrical branches (Desqueyroux 1972)), absence of rhabdostyles (present in A. cylindrica sp. nov.) and presence of long thin styles with curved head (absent in $A$. coronata sp. nov.). In Table 5, the other geographically close species of Axinella and other species recorded in the Southern Hemisphere are reported. All of these species differ from A. cylindrica sp. nov. and A. coronata sp. nov. in the external morphology, and the type and size of spicules. Moreover A. cylindrica sp. nov. differs from all the other species in the presence of rhabdostyles (Table 5).

Order Biemnida Morrow, 2013

Family Biemnidae Hentschel, 1923

Genus Biemna Gray, 1867

Biemna aurantiaca Bertolino, Costa \& Pansini sp. nov. urn:1sid:zoobank.org:act:DD1D8BC5-DCF9-4294-9FA4-80FFD911417C

Figs 7-8; Table 6

\section{Etymology}

The new species is named after its orange colour.

\section{Type material}

\section{Holotype}

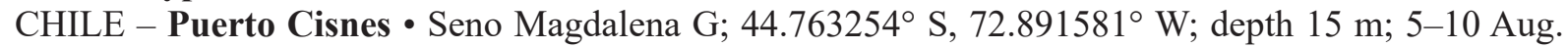
2016; Marco Bertolino leg.; on a rocky slope by scuba diving; CILE 20; MSGN 61497.

\section{Paratype}

CHILE - Puerto Cisnes 1 specimen; same collection data as for holotype; CILE 6; DISTAV.

\section{Description}

Habitus. Cushion-shaped sponge, almost spherical, $3.5 \mathrm{~cm}$ in diameter and $\mathrm{ca} 2 \mathrm{~cm}$ thick. Canal system visible, converging towards round flush oscula. Surface slightly hispid, colour in life bright orange (Fig. 7A-B). Consistency soft and friable.

Skeleton. Plumoreticulate choanosome (Fig. 7C) with spongin fibres cored by bundles of spicules typical of Biemnidae. Sponge surface appears slightly hispid due to single protruding spicules (Fig. 7C).

SPICULES. Megascleres: Smooth sinuous styles, with regular, round heads (Fig. 8A), 700-(842.5)$920 \mu \mathrm{m}$ long and 2.5-(4.8)-7.5 $\mu \mathrm{m}$ thick. Tylostyles sometimes slightly bent near head (Fig. 8B), 120-(269.25)-380 $\mu \mathrm{m}$ long and 5-(12.9)-20 $\mu \mathrm{m}$ thick. Microscleres: two categories of raphids; I, long and thin raphids, curved or slightly sinuous, 105-(129.5)-200 $\mu \mathrm{m}$ long, with microspined extremities (Fig. 8C); II, short and thick raphidioid microxeas with small scattered spines (Fig. 8D), 27.5-(35.6)$40 \times 2 \mu \mathrm{m}$ long. $\mathrm{C}$-shaped sigmas with microspined extremities, divided into two size categories: sigmas I, 130-(160.8)-170 $\mu \mathrm{m}$ long and $\times 5-(5.7)-7.5 \mu \mathrm{m}$ thick (Fig. 8E); sigmas II, 12.5-(13.12)-17.5 $\mu \mathrm{m}$ long (Fig. 8F). 


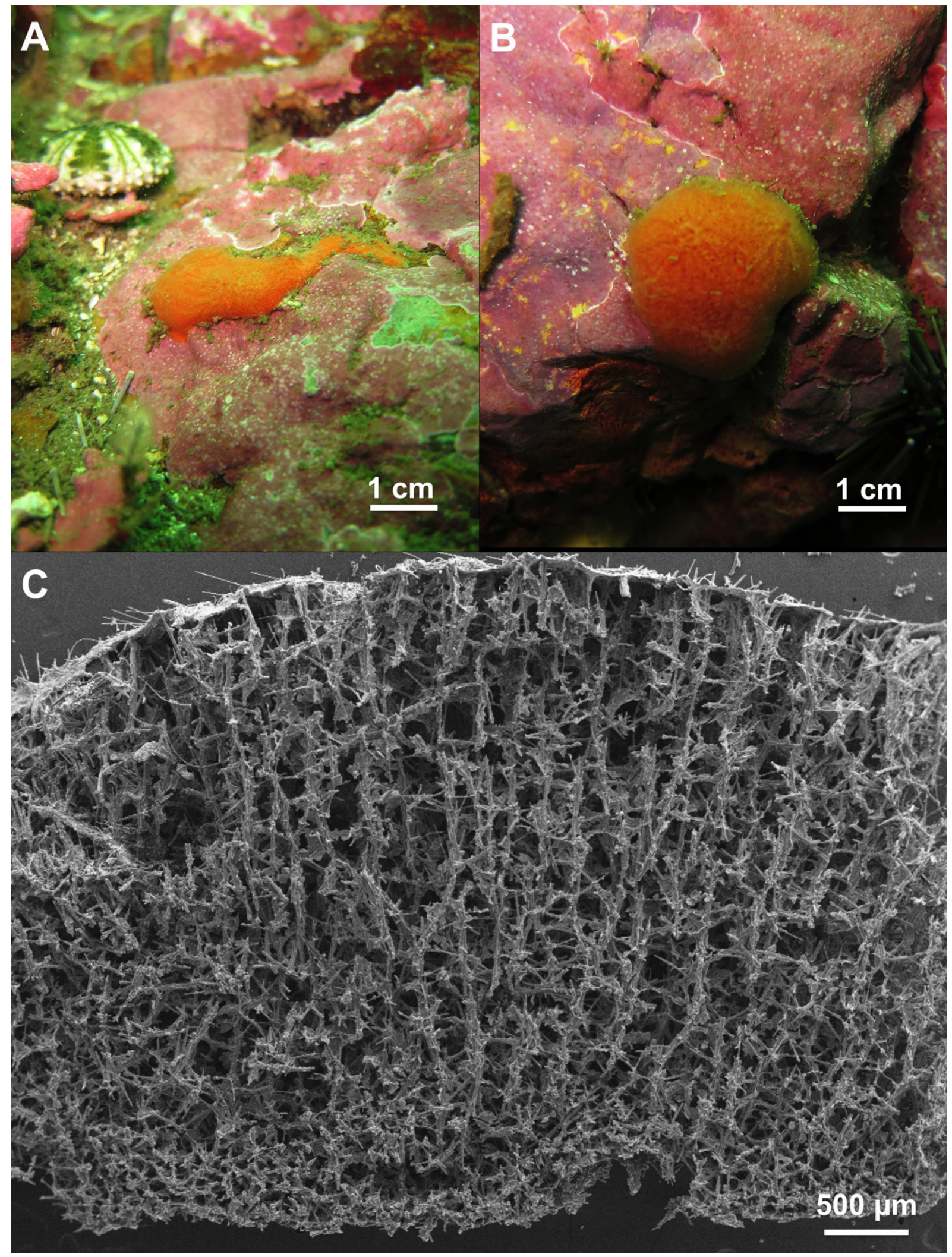

Fig. 7. Biemna aurantiaca Bertolino, Costa \& Pansini sp. nov., holotype (CILE 20; MSGN 61497). A-B. The holotype in life. C. Plumoreticulate skeleton. 


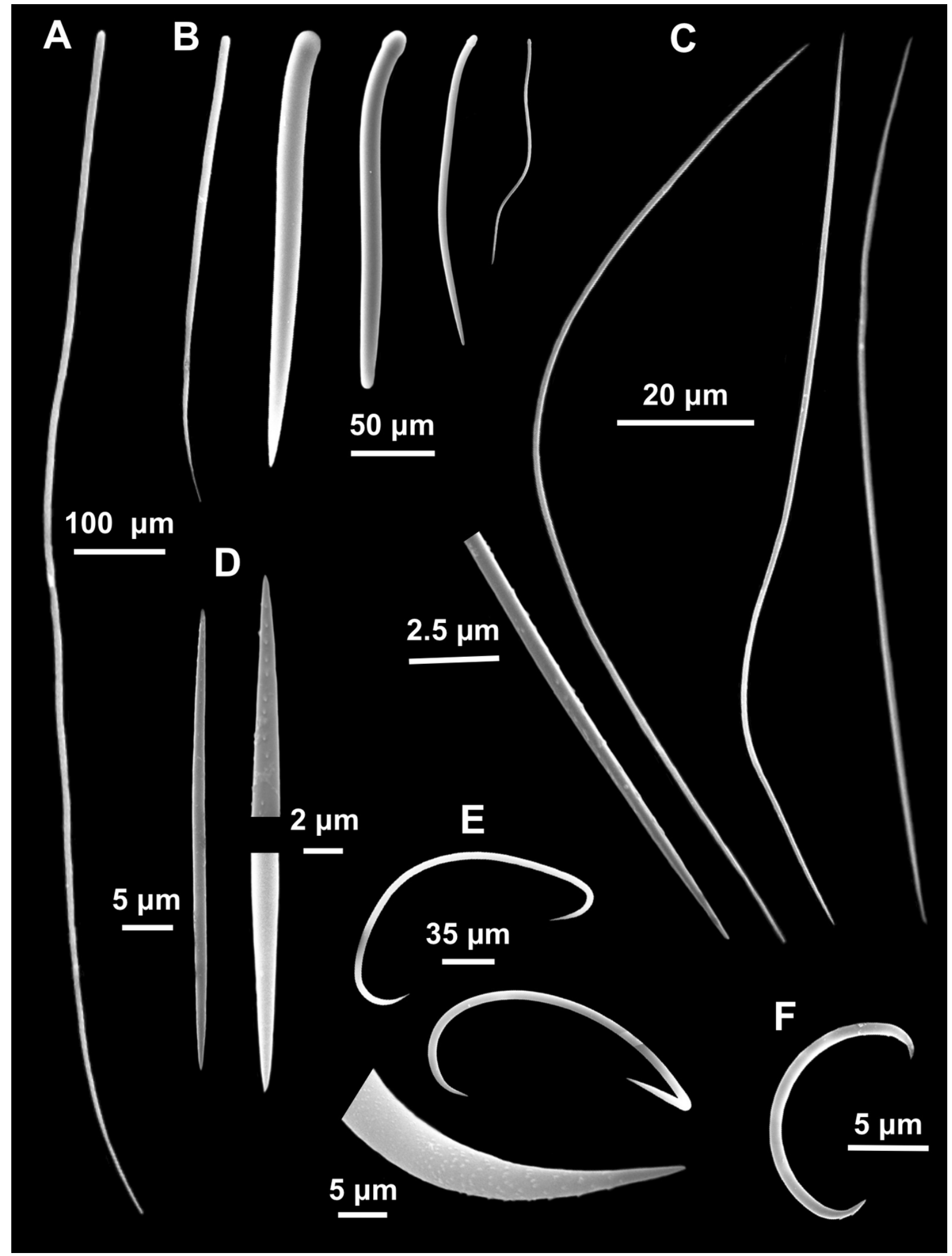

Fig. 8. Spicules of Biemna aurantiaca Bertolino, Costa \& Pansini sp. nov., holotype (CILE 20; MSGN 61497). A. Sinuous styles. B. Tylostyles. C. Raphids I. D. Raphids II. E. Sigma I. F. Sigma II. 


\section{Habitat}

Species lives at a depth of $20 \mathrm{~m}$ on a vertical wall.

\section{Remarks}

We have recorded three new species of the genus Biemna and have therefore decided to make combined remarks after their description.

Biemna erecta Bertolino, Costa \& Pansini sp. nov.

urn:1sid:zoobank.org:act:F0A045BB-EE04-4239-94C8-C3025A29B450

Figs 9-10; Table 6

\section{Etymology}

The new species is named after its growth form.

\section{Type material}

\section{Holotype}

CHILE - Puerto Cisnes • Seno Magdalena D; 44.614863 S, 72.958312 W; depth 20 m; 5-10 Aug. 2016; Marco Bertolino leg.; on a vertical wall by scuba diving; CILE 74; MSGN 61496.

\section{Description}

Habitus. Fan-shaped lamellar sponge, about $3 \mathrm{~mm}$ thick and $3.5 \mathrm{~cm}$ long, with basal peduncle. Surface very hispid caused by megascleres protruding from surface. Colour in life pale yellow, tending to orange (Fig. 9A-B). Consistency soft, compressible and friable in dry state.

Skeleton. Plumose skeleton formed by dense fibres of spicules whose extremities protrude through surface of sponge, resulting in hispid appearance (Fig. 9C). Choanosome differentiated into two regions composed of axial compressed and extra-axial plumose fibres (Fig. 9D-E). Basal peduncle formed by ascending central fibres with radial spicules (Fig. 9F).

SPICULES. Megascleres: Styles smooth and sinuous, with regular round heads (Fig. 10A), 1810.5(2033.3)-2295 $\mu \mathrm{m}$ long and 15-(17.5)-20 $\mu \mathrm{m}$ thick; tylostyles/subtylostyles slightly curved near the head (Fig. 10B), 350-(607.5)-960 $\mu \mathrm{m}$ long and 10-(18.75)-30 $\mu \mathrm{m}$ thick. Microscleres: Two categories of raphids; I, sinuous and thin raphids (Fig. 10C), 87.5-(115)-167.5 $\mu \mathrm{m}$ long; II, short and thick raphids, with small scattered spines, similar to raphidioid microxeas, 23.4-(36.55)-42.5 $\mu \mathrm{m}$ long and $2 \mu \mathrm{m}$ thick (Fig. 10D). C-shaped sigmas with microspined extremities clearly divided into two size categories: sigmas I, (Fig. 10E), 140-(159.5)-180 $\mu \mathrm{m}$ long and 5-(5.7)-7.5 $\mu \mathrm{m}$ thick; and sigmas II, (Fig. 10F), only $10-(14.5)-17.5 \mu \mathrm{m}$ long.

\section{Habitat}

Species lives on a vertical wall at a depth of $20 \mathrm{~m}$.

\section{Remarks}

We have recorded three new species of the genus Biemna and have therefore decided to make combined remarks after their description. 


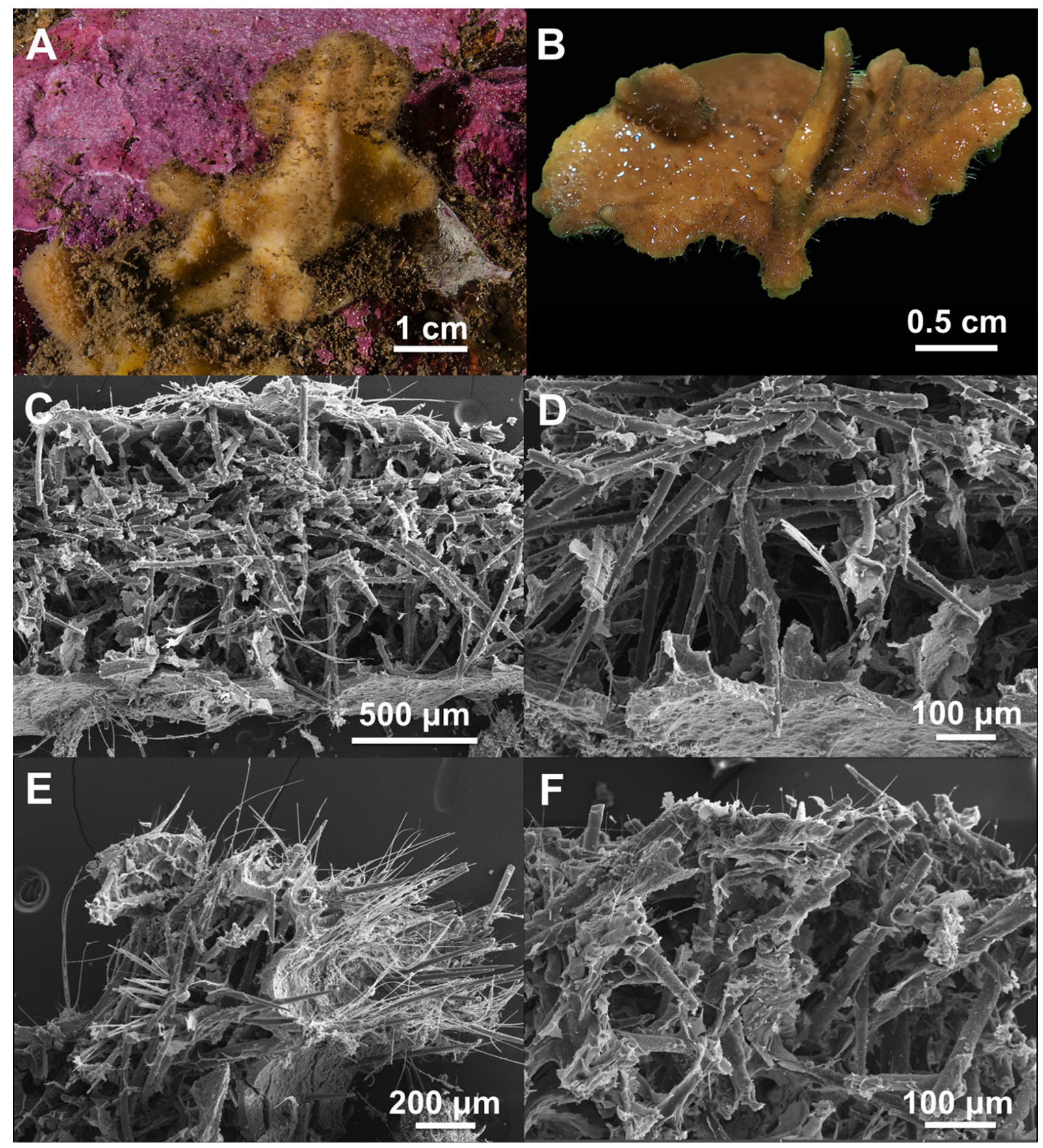

Fig. 9. Biemna erecta Bertolino, Costa \& Pansini sp. nov., holotype (CILE 74; MSGN 61496). A-B. The holotype in life. C. Plumose skeleton. D-E. Choanosome. F. Basal peduncle skeleton. 


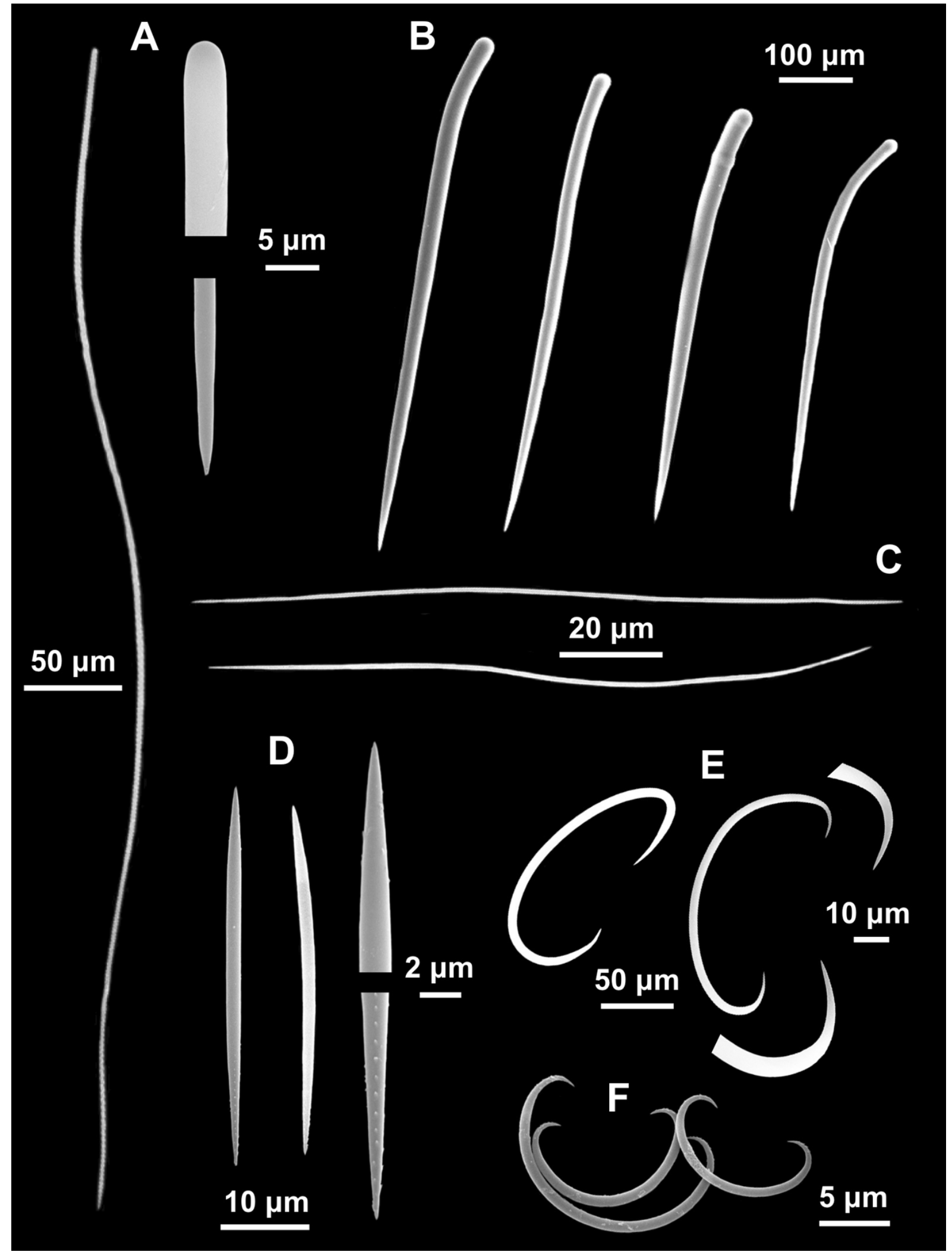

Fig. 10. Spicules of Biemna erecta Bertolino, Costa \& Pansini sp. nov., holotype (CILE 74; MSGN 61496). A. Styles. B. Tylostyles/subtylostyles. C. Raphids I. D. Raphids II. E. Sigma I. F. Sigma II. 
Biemna typica Bertolino, Costa \& Pansini sp. nov. urn:Isid:zoobank.org:act:00C6E35C-E9FE-4F3D-A752-1A91D11BAC1C

Figs 11-12; Table 6

\section{Etymology}

The new species is named after its spicule complement typical of the genus.

\section{Type material}

\section{Holotype}

CHILE - Puerto Cisnes • Seno Magdalena G; 44.763254 S, $72.891581^{\circ} \mathrm{W}$; depth 15 m; 5-10 Aug. 2016; Marco Bertolino leg.; on a rocky slope by scuba diving; CILE 28; MSGN 61495.

\section{Description}

Habitus. Massive, cushion shaped sponge, rather regular, ca $2 \mathrm{~cm}$ long and $2 \mathrm{~cm}$ thick, with very hispid surface. Colour in life bright red, remaining unchanged out of the water. Sponge compressible and friable (Fig. 11A).

Skeleton. Structure typical of Biemnidae, plumose and with variable development of spongin fibres (Fig. 11B). Choanosome plumoreticulate, with spongin fibres covered by bundles of spicules (styles) and oxeote spicules that - protruding through sponge surface - make it hispid. Ectosomal skeleton composed of brushes of megascleres (Fig. 11C-D).

SPICULES. Megascleres: Styles I smooth, straight, slightly sinuous and thin, with regular, round heads (Fig. 12A), 1275-(1450.8)-1632 $\mu \mathrm{m}$ long and 5.2-(6.5)-7.8 $\mu \mathrm{m}$ thick; styles II smooth, curved and very thin (Fig. 12B), 293.6-(340.3)-365.22 $\mu \mathrm{m}$ long and 2-(2.25)-2.5 $\mu \mathrm{m}$ thick; styles III straight, curved or doubly bent, sometimes modified to rhabdostyles (Fig. 12C), 220-(409.7)-640 $\mu \mathrm{m}$ long and 10.4-(13.76)-20.8 $\mu \mathrm{m}$ thick. Microscleres: two raphid categories; raphids I, straight or sinuous (Fig. 12D), 87.5-(115)-167.5 $\mu \mathrm{m}$ long; raphids II, short and thick, similar to raphidioid microxeas with one microspined tip (Fig. 12E), 23.4-(36.55)-42.5 $\mu \mathrm{m}$ long. C-shaped sigmas with microspined extremities clearly divided into two size categories: sigmas I, (Fig. 12F),145.5-(136.7)-152 $\mu \mathrm{m}$ long and $2.6 \mu \mathrm{m}$ thick; sigmas II, (Fig. 12G), 12.5-(19.8)-22.5 $\mu \mathrm{m}$ long.

\section{Habitat}

Species lives on a rocky slope covered by coralline algae, at a depth between 15 and $20 \mathrm{~m}$.

\section{Remarks}

The three new species, Biemna aurantiaca sp. nov., B. erecta sp. nov. and B. typica sp. nov., differ from each other primarily in their external morphology and colour (see descriptions above and Table 6). Regarding megascleres, B. aurantiaca sp. nov. has smaller styles and tylostyles than B. erecta sp. nov., while $B$. typica sp. nov. has only three categories of styles, with no tylostyles. Furthermore, the microscleres differ in size between the three new species which are, therefore, clearly distinguishable from each other. From the cold waters of the Southern Hemisphere, twelve species of the genus Biemna are known (Table 6). Two of these have been reported on the Chilean coast: B. chilensis Thiele, 1905 and B. lutea Bertolino, Costa \& Pansini, 2019. The new species described in the present study differ from these two species in the presence of more categories of styles and different forms of spicules. Additionally, only one category of raphids is present in B. chilensis (see Table 6). Biemna typica sp. nov. differs from all other Biemna listed in Table 6 in the presence of only one category of styles. Biemna erecta sp. nov. and $B$. aurantiaca sp. nov. have spicule complements similar to $B$. rhabderemioides 
Bergquist, 1961 and B. rhabdostyla Uriz, 1988, but the latter two species possess much smaller styles and subtylostyles (Table 6).

In conclusion, the three species described here (Biemna aurantiaca sp. nov., B. erecta sp. nov and B. typica sp. nov.) differ from each other in the size and shape of the spicules, and should be considered as new species.

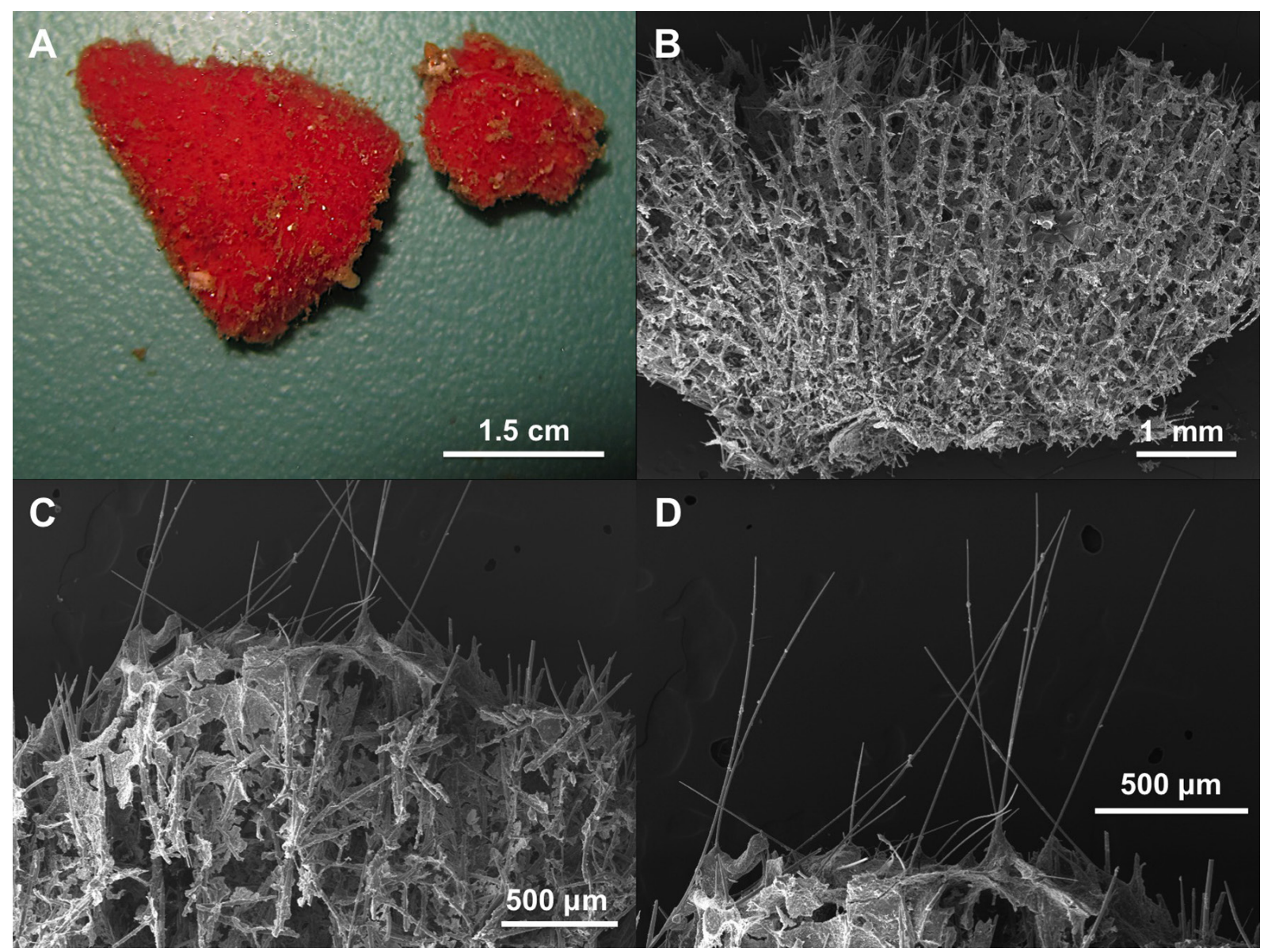

Fig. 11. Biemna typica Bertolino, Costa \& Pansini sp. nov., holotype (CILE 28; MSGN 61495). A. The holotype in life. B. Plumose skeleton. C-D. Ectosomal skeleton. 


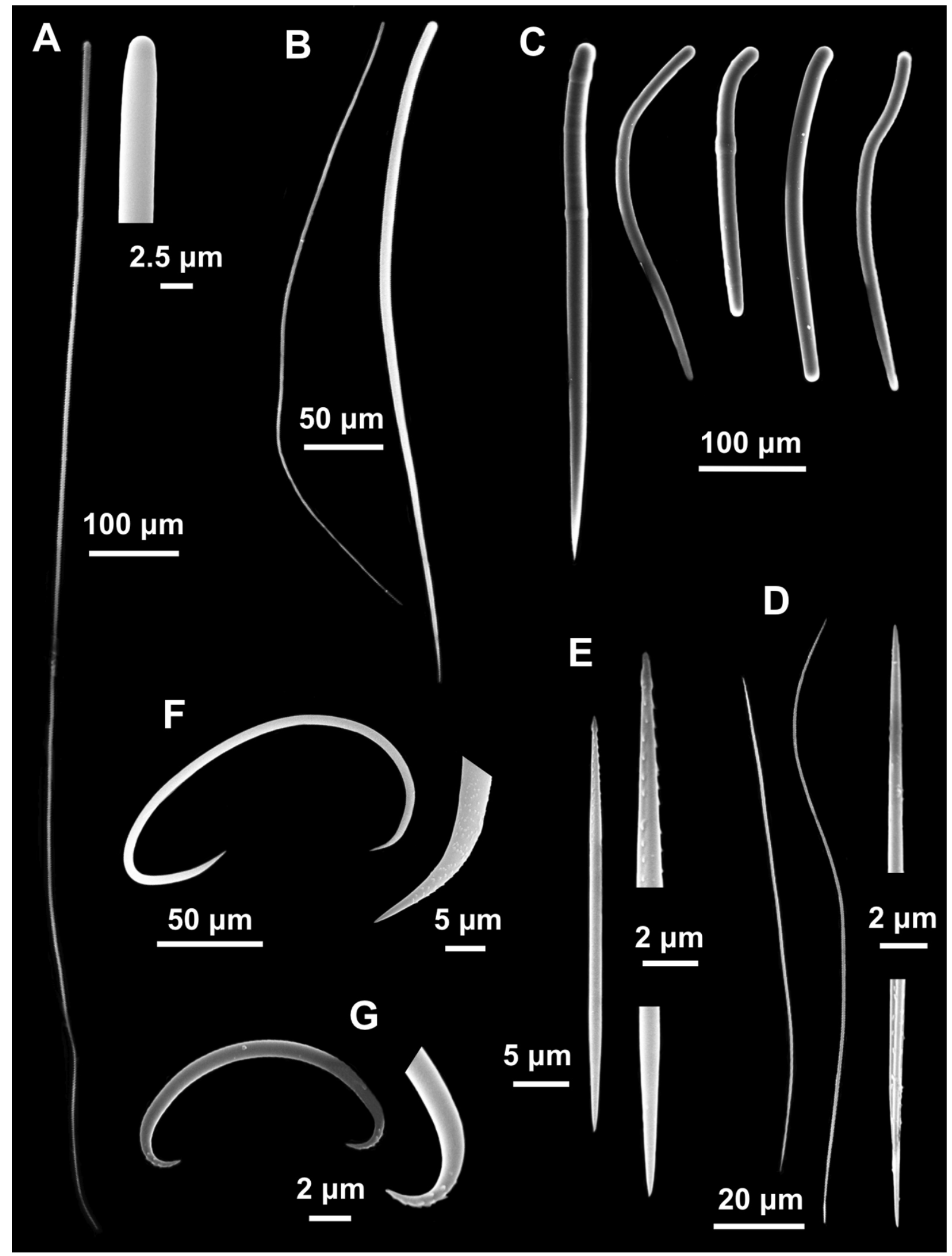

Fig. 12. Spicules of Biemna typica Bertolino, Costa \& Pansini sp. nov., holotype (CILE 28; MSGN 61495). A. Styles I. B. Styles II. C. Styles III, sometimes modified to rhabdostyles. D. Raphids I. E. Raphids II. F. Sigmas I. G. Sigmas II. 


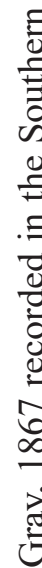

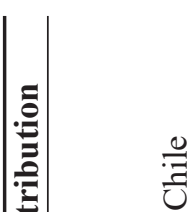

$\stackrel{0}{\frac{0}{3}}$

$\stackrel{0}{\Xi}$

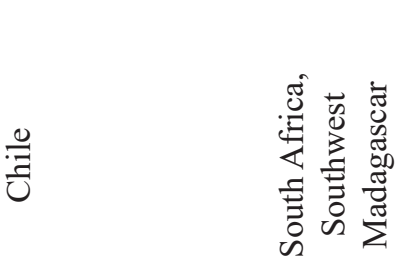

$\Xi \quad \frac{n}{\circ}$

हैं

(2)

$\stackrel{\text { Tे }}{1}$

n. $\stackrel{\infty}{i} \stackrel{n}{i}$

is $\frac{1}{3}$

$\frac{1}{i}$

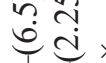

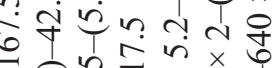

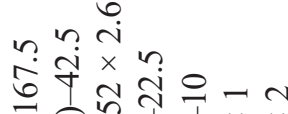

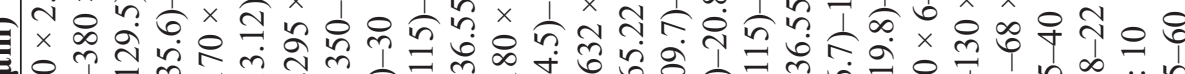

更

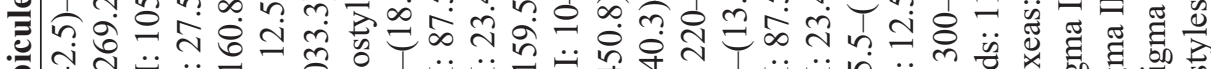

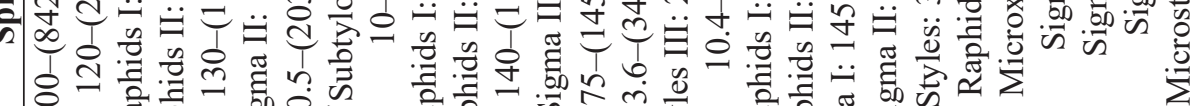

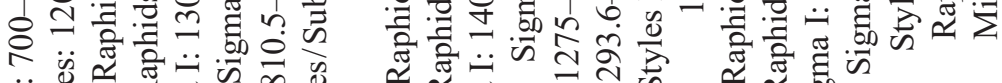

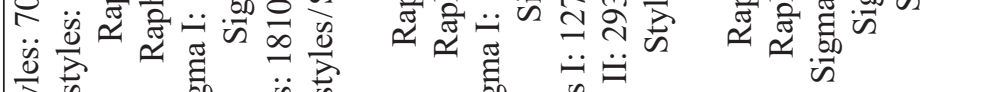

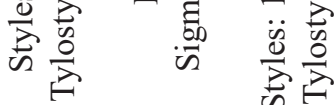

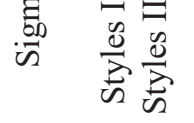

昜
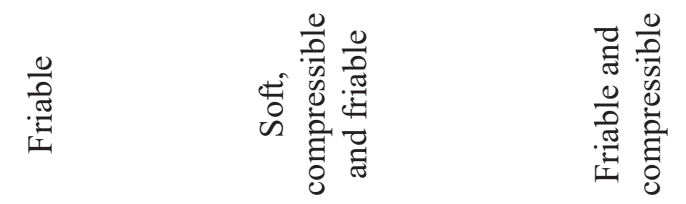

$\frac{0}{\frac{0}{0}}$

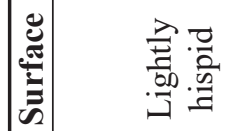

氛

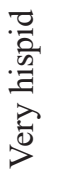

己ี

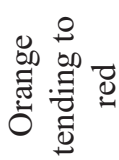

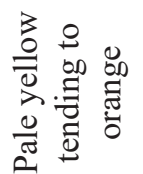

总

$\frac{3}{2}$

㝘

品

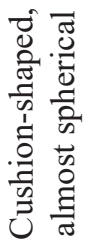

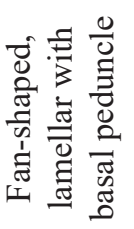

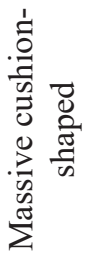

0
0
0
0
$\Sigma$
$\Sigma$

峞

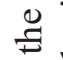
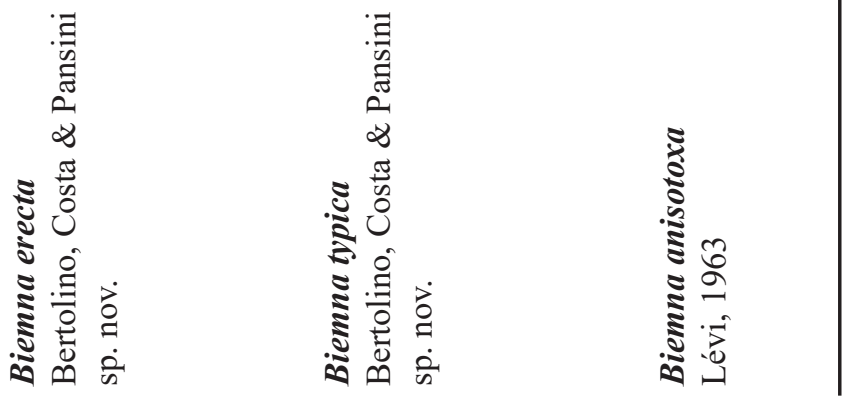


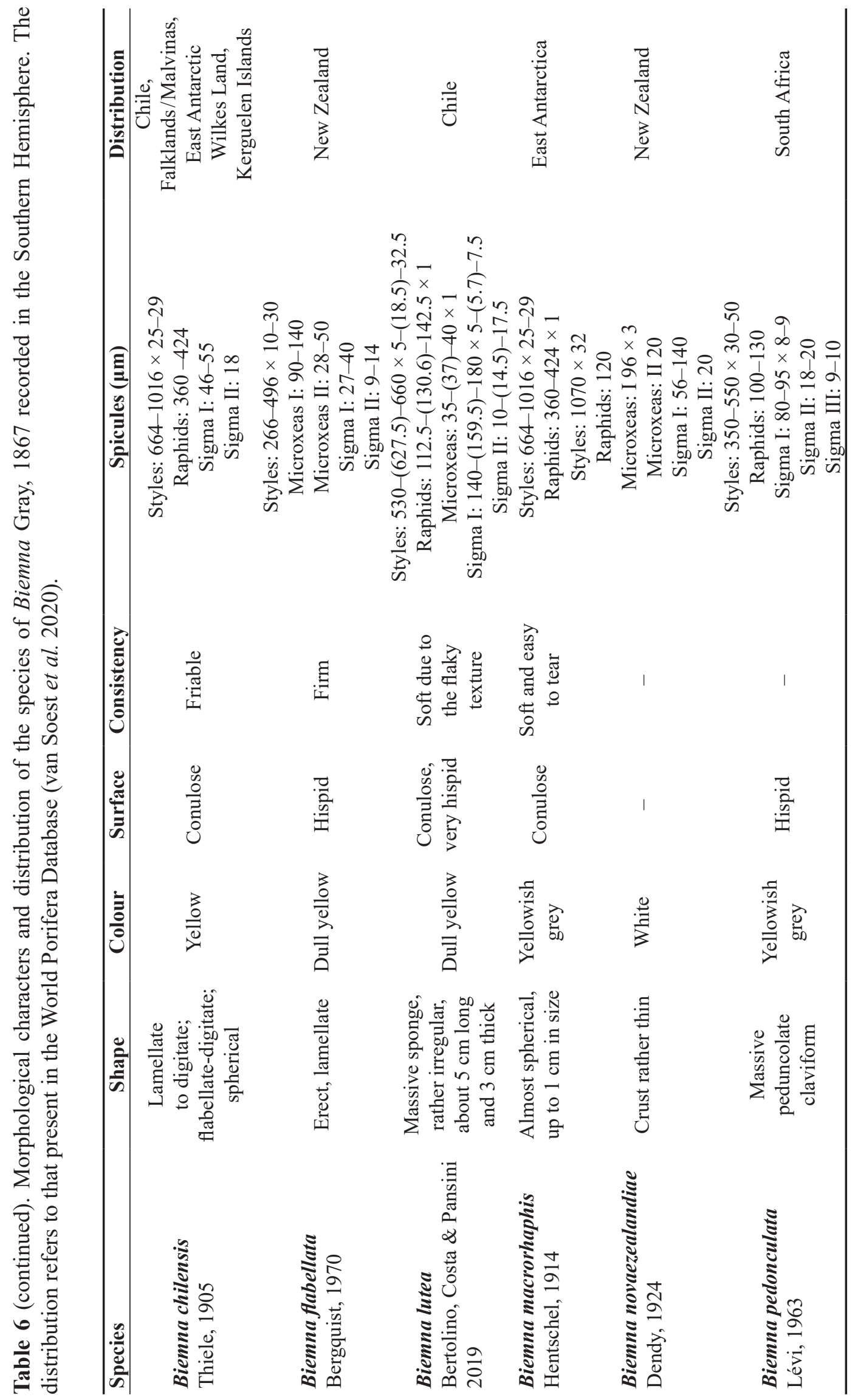




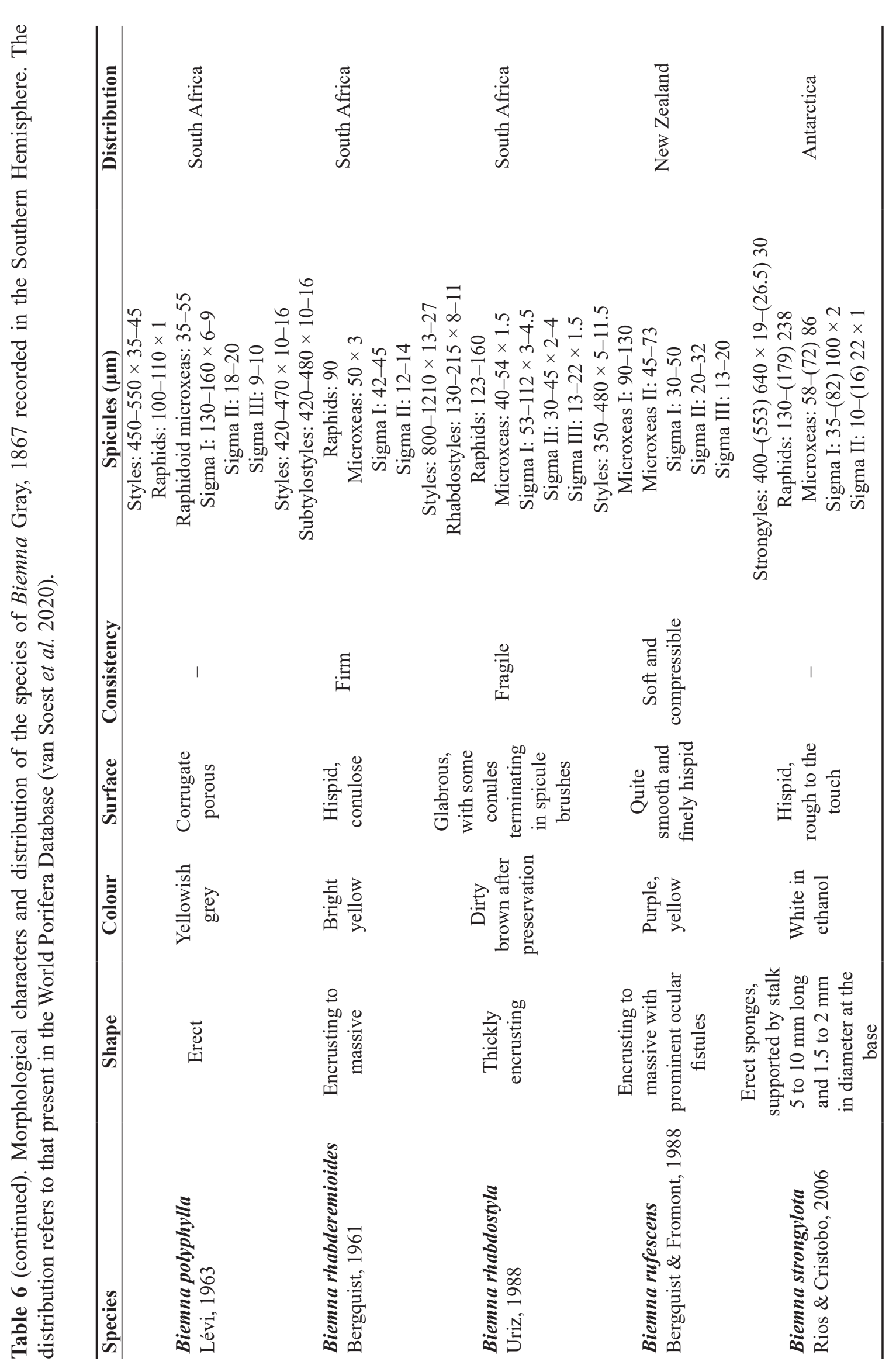


Order Scopalinida Morrow \& Cárdenas, 2015

Family Scopalinidae Morrow, Picton, Erpenbeck, Boury-Esnault, Maggs \& Allcock, 2012

Genus Scopalina Schmidt, 1862

Scopalina cribrosa Bertolino, Costa \& Pansini sp. nov.

urn:1sid:zoobank.org:act:2C1EE9CB-2950-4449-AD77-D32D9A781E9C

Fig. 13; Table 7

\section{Etymology}

The new species is named after the cribrose surface of the sponge.

\section{Type material}

\section{Holotype}

CHILE - Puerto Cisnes • Jacaf Canal N; 44.271194오 S, 73.209222 ${ }^{\circ}$ W; depth 20 m; 5-10 Aug. 2016; Marco Bertolino leg.; on a rocky slope by scuba diving; CILE 32; MSGN 61498.

\section{Description}

Habitus. Encrusting sponge $5 \mathrm{~mm}$ thick and $10 \mathrm{~cm}$ long (Fig. 13A). Surface slightly conulose with visible oscula, ostia and canal network. Slightly hispid. Colour in life reddish orange (Fig. 13A). Consistency soft.

Skeleton. Choanosomal skeleton consisting of bundles of thin styles entirely enclosed in spongin. Dendritic fibres rising up from basal spongin plate. Low spicular density.

SPICULES. Megascleres: Smooth styles, bent near the head, ending with tip not pointed but almost rounded (Fig. 13B-C), 520-(1616.15)-2091 $\mu \mathrm{m}$ long and 2.5-(23.25)-32.5 $\mu \mathrm{m}$ thick.

\section{Habitat}

Species lives at a depth of $20 \mathrm{~m}$, on a rocky slope covered by coralline algae.

\section{Remarks}

From five species of the Scopalina genus known in the Southern Hemisphere (Table 7), only Scopalina bunkeri Goodwin, Jones, Neely \& Brickle, 2011 has been recorded from Chilean coast by Bertolino et al. (2019). The new species differs from $S$. bunkeri in having a very spiky surface and by the presence of smaller styles (Table 7). Scopalina cribrosa sp. nov. differs from S. australiensis (Pulitzer-Finali, 1982) from Eastern Australia in its external morphology, having an erect habit, large body and spicule size, but much smaller styles (Table 7). Scopalina cribrosa sp. nov. differs from S. erubescens Goodwin, Jones, Neely \& Brickle, 2011 from the Falklands / Malvinas in its pale pink colour, a conulose surface, and styles that are four times shorter than those of S. erubescens (Table 7). Scopalina cribrosa sp. nov. differs from S. hapalia (Hooper, Cook, Hobbs \& Kennedy, 1997) from Australia both in the colour and the presence of strongyles, which are lacking in the new species. Finally, regarding species of the Southern Hemisphere, S. cribrosa sp. nov. differs from S. incrustans (Lendenfeld, 1887) from Australia by its larger styles. The nine species of Scopalina reported from the Northern Hemisphere differ from S. cribrosa in the size of spicules, and often in their shape (Table 7). We, therefore, propose that Scopalina cribrosa sp. nov. should be considered as a species new to science. 


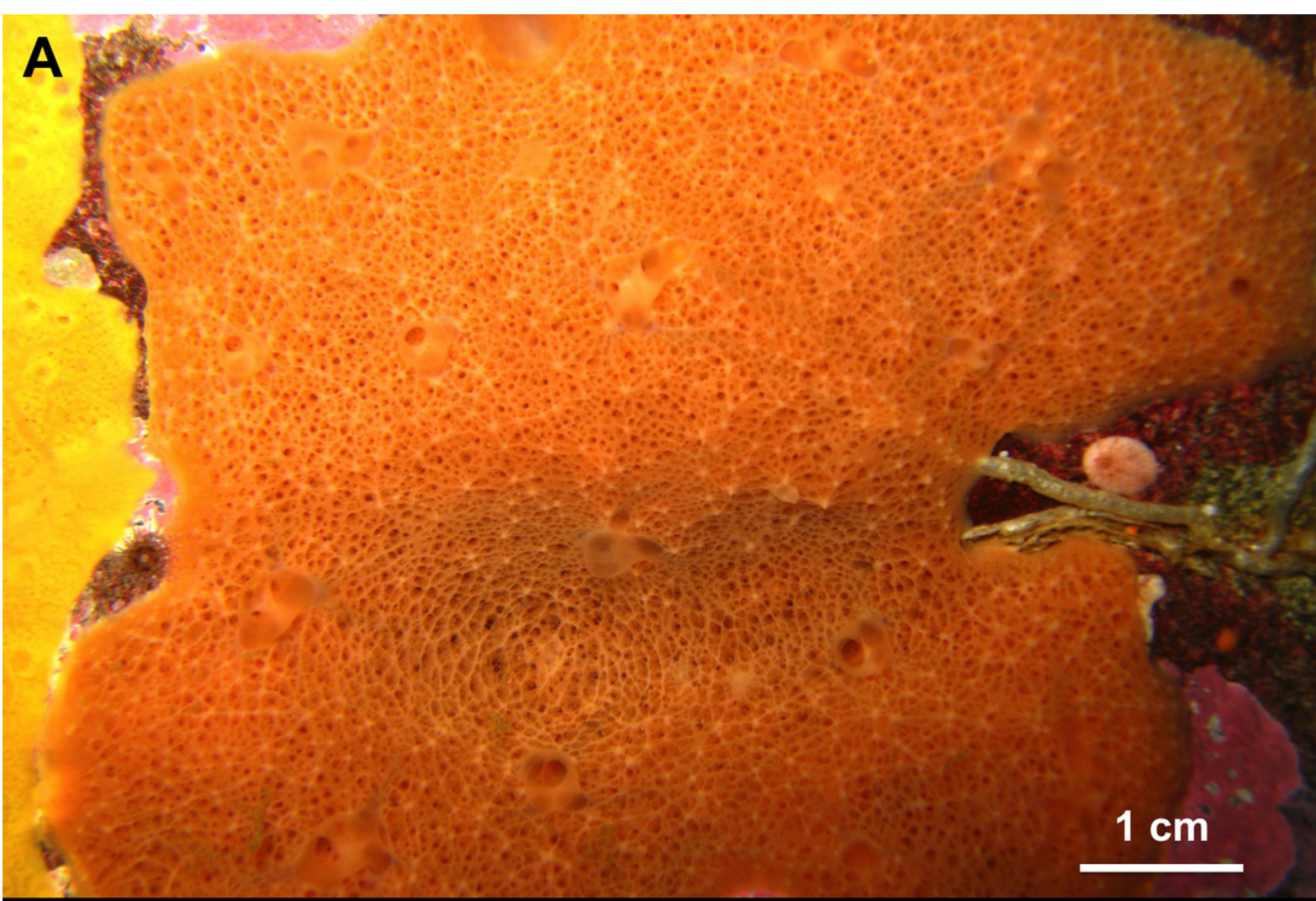

B

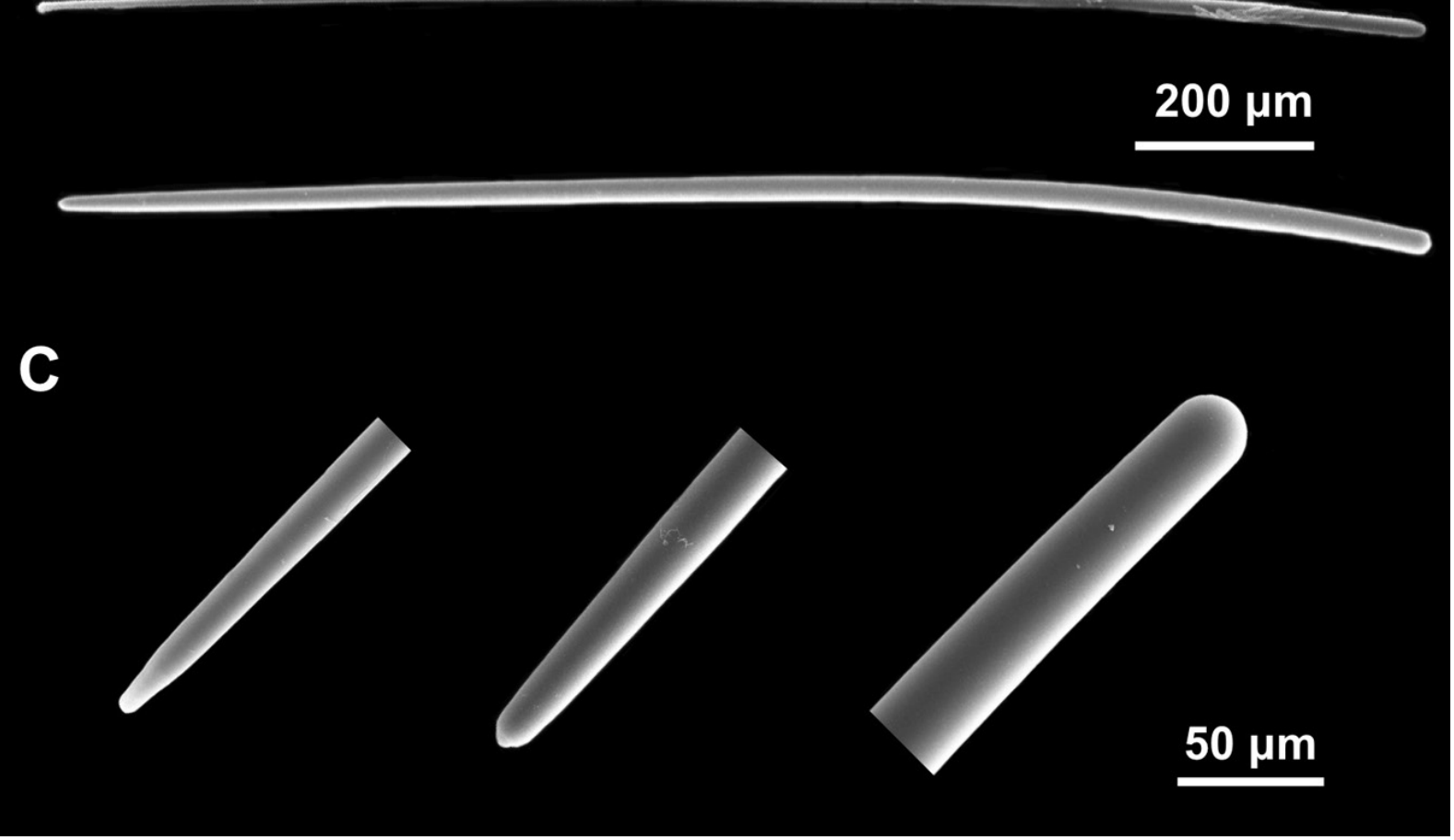

Fig. 13. Scopalina cribrosa Bertolino, Costa \& Pansini sp. nov., holotype (CILE 32; MSGN 61498). A. The holotype in life. B. Styles. C. Magnification of the style ends. 


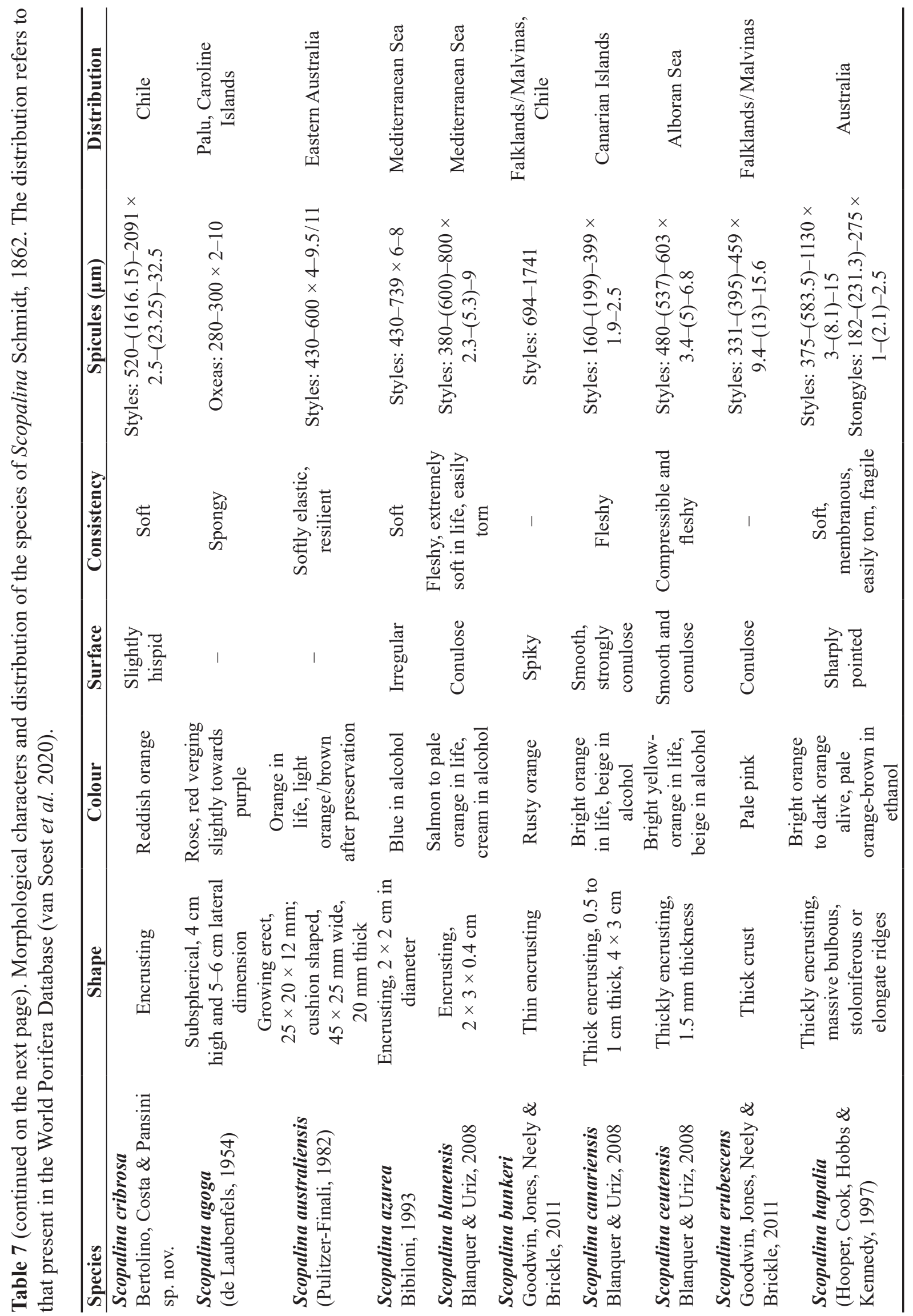




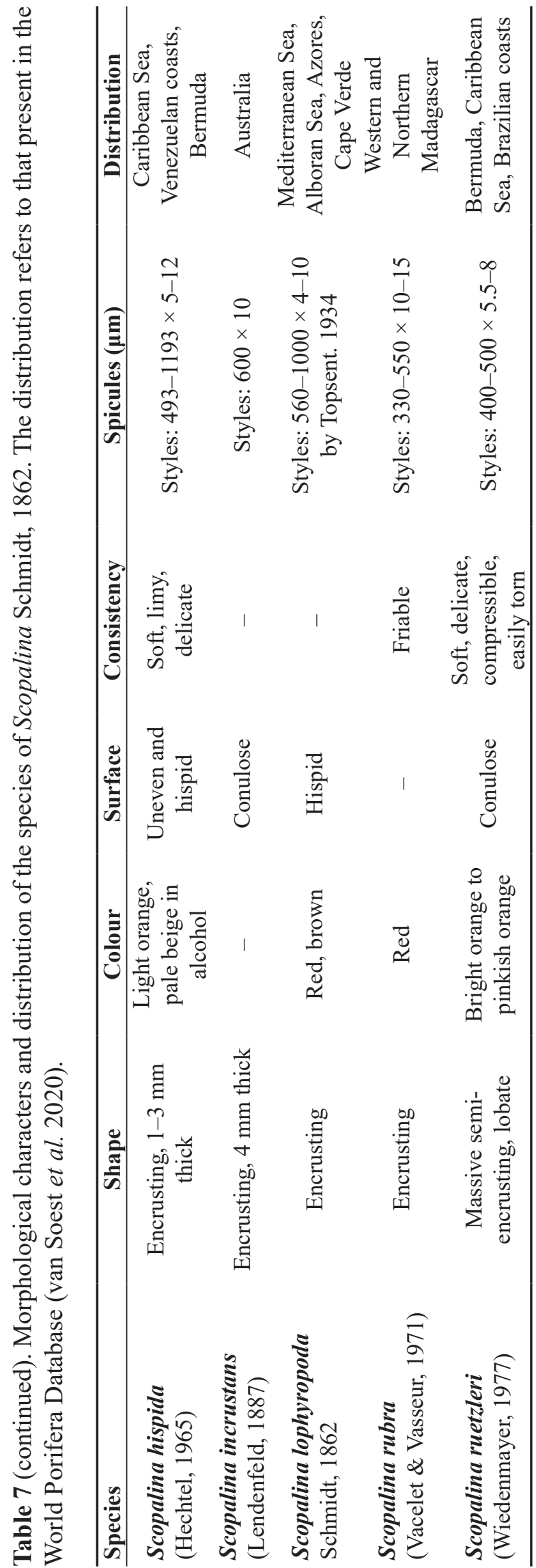


Order Suberitida Chombard \& Boury-Esnault, 1999

Family Suberitidae Schmidt, 1870

Genus Rhizaxinella Keller, 1880

Rhizaxinella strongylata Bertolino, Costa \& Pansini sp. nov. urn:1sid:zoobank.org:act:78052288-83C4-4D9F-91DE-6275C19187CE

Fig. 14

\section{Etymology}

The new species is so named for the presence of strongyloid styles in the spicules.

\section{Type material}

\section{Holotype}

CHILE - Puerto Cisnes • Seno Magdalena D; 44.614863 S, $72.958312^{\circ} \mathrm{W}$; depth $25 \mathrm{~m}$; 5-10 Aug. 2016; Marco Bertolino leg.; on a vertical wall by scuba diving; CILE 65; MSGN 61499.

\section{Description}

Habitus. Small erect sponge, $5 \mathrm{~cm}$ high, with thin stalk ( $5 \mathrm{~mm}$ in diameter) which divides into two branches with peariform extremities (Fig. 14A). Two round oscula visible. Surface hispid. Colour in life bright yellow (Fig. 14A). Consistency strong but compressible.

SkELETON. Stalk characterized by axial compact skeleton that diverges into thinner secondary axes in branches. Close to surface ectosomal skeleton composed of brushes of spicules.

SPICULES. Megascleres: Smooth, slightly curved, long tylostyles (Fig. 14B), 841.5-(1466.3)-2320.5 $\mu \mathrm{m}$ long and 17.5-(21.75)-30 $\mu \mathrm{m}$ thick. Shorter, straight or curved, often fusiform tylostyles, with different heads (Fig. 14C), 175-(230.25)-320 $\mu \mathrm{m}$ long and 10-(14.1)-17.5 $\mu \mathrm{m}$ thick. Smooth strongyloid styles, more or less curved (Fig. 14D), 200-(274.55)-340 $\mu \mathrm{m}$ long and 10-(18.75)-25 $\mu \mathrm{m}$ thick.

\section{Habitat}

Species lives at a depth between 20 and $25 \mathrm{~m}$ on a vertical wall.

\section{Remarks}

Only one species of this genus has been reported from the channels and fjords of southern Chile: Rhizaxinella spiralis (Ridley \& Dendy, 1886). The new species $R$. strongylata sp. nov. described here differs from $R$. spiralis in external morphology, shape and size of styles/tylostyles, and in the presence of strongyloid spicules. In fact, $R$. spiralis has a stipitate cylindrical shape and two categories of tylostyles/styles that measure $1000 \times 13 \mu \mathrm{m}$ and $400 \mu \mathrm{m}$ (width not reported in original description).

Four other Rhizaxinella species are present in the Southern Hemisphere and so geographically closer to the new species. Rhizaxinella australiensis Hentschel, 1909 (North Patagonian Gulf, East Antarctic Wilkes Land, West Australia) is ramified with vertical branches; tylostyles are sinuous, straight or strongyloid and measure 500-1200 ×9-19 $\mu \mathrm{m}$ and 240-500 ×9-12 $\mu \mathrm{m}$. Rhizaxinella dichotoma Lévi, 1993 (New Zealand, New Caledonia) is pedunculate with multiple branches, has principal tylostyles (725-1200 $\times$ 15-30 $\mu \mathrm{m})$ and peripheral tylostyles $(400-800 \times 4-10 \mu \mathrm{m})$. Rhizaxinella durissima (Ridley \& Dendy, 1886) (Southwest Australia) with pedunculate shape has straight styles/tylostyles $(240 \times 6.3 \mu \mathrm{m})$ and fusiform tylostyles $(1500 \times 15.7 \mu \mathrm{m})$. The species morphologically closest to the new species, based on the large spicules and the presence of strongyloid forms, appears to be $R$. radiata Hentschel, 1909 (West Australia) which has a pedunculate shape, straight styles $(1100-2150 \times 27-45 \mu \mathrm{m})$, styles/subtylostyles 


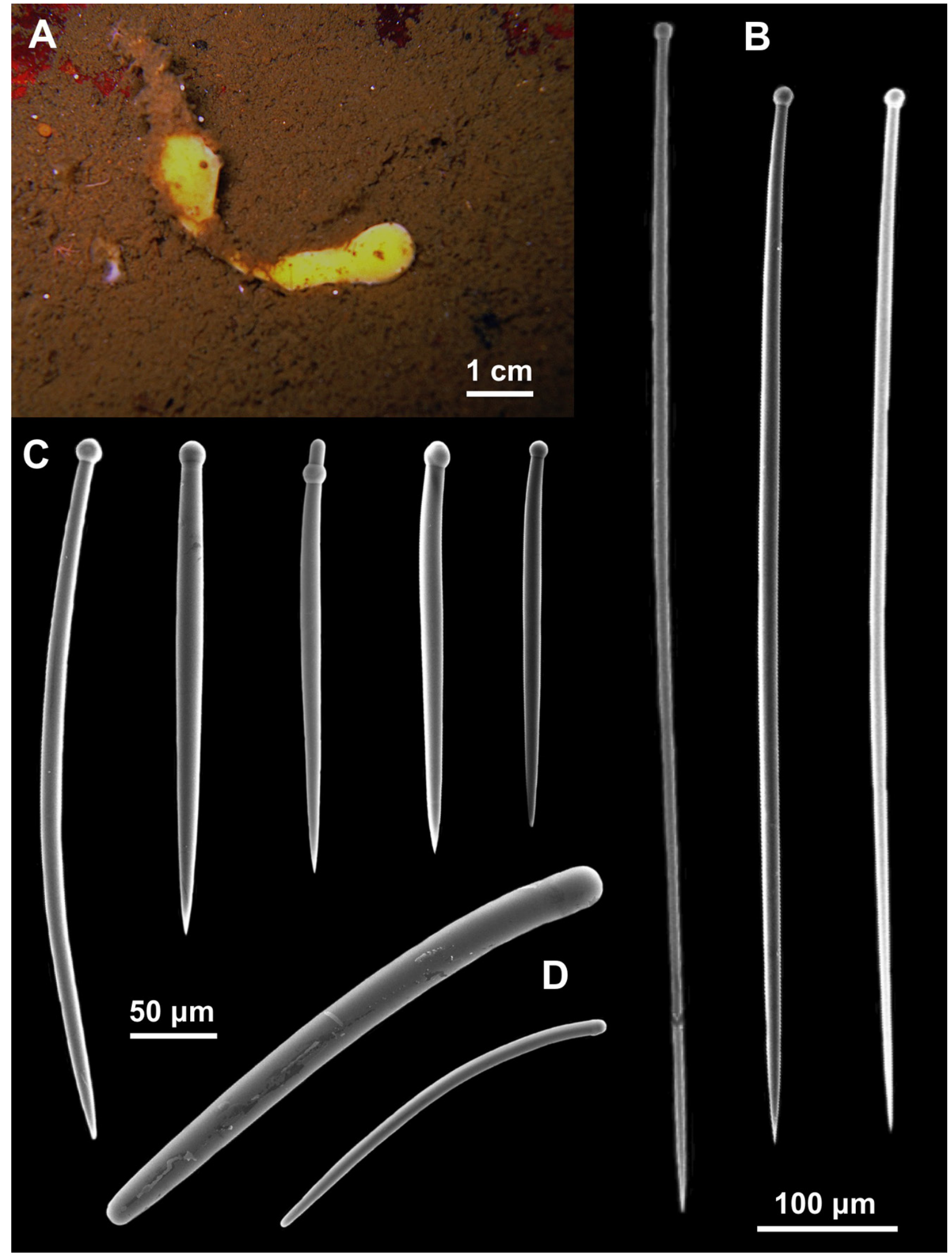

Fig. 14. Rhizaxinella strongylata Bertolino, Costa \& Pansini sp. nov., holotype (CILE 65; MSGN 61499). A. The holotype in life. B. Tylostyles I. C. Tylostyles II. D. Strongyloid styles. 
$(250-800 \times 10-17 \mu \mathrm{m})$ and strongyles $(250-350 \times 7-11.2 \mu \mathrm{m})$. Even allowing for the lesser importance of sponge shape and a degree of morphological variability within the genus, the present description of type and size of spicules of $R$. strongylata sp. nov. merits the establishment of a new species.

Subclass Keratosa Grant, 1861

Order Dendroceratida Minchin, 1900

Family Darwinellidae Merejkowsky, 1879

Genus Darwinella Müller, 1865

\section{Type species}

Darwinella muelleri (Schultze, 1865).

\section{Emended diagnosis}

In the Darwinella, the dendritic fibre skeleton is supplemented by fibrous spicules which can be diactinal, triactinal or polyactinal. There is no sand in the fibres but dispersed cellular elements can occur. The sponges are fleshy, encrusting, or massive to lobate; to which fibrous spicule with style shape may be added (emended from Müller 1865).

\section{Remarks}

The species of Darwinella may be confused with those belonging to the genus Aplysilla Schulze, 1878 because of the similarity in external shape; however, Darwinella is characterized by the presence of diactinal, triactinal or polyactinal fibrous spicules (Pronzato 1975). In the present study we described a new fibrous spicule type for the Darwinella genus.

Darwinella pronzatoi Bertolino, Costa \& Pansini sp. nov. urn:1sid:zoobank.org:act:FA17C8DB-1973-4E6F-9AB9-A025F68D38F5

Fig. 15

\section{Etymology}

The new species is named after Professor Roberto Pronzato (DISTAV - Università degli Studi di Genova) in recognition of his significant contributions to taxonomic studies on horny sponges.

\section{Type material}

\section{Holotype}

CHILE - Puerto Cisnes • Seno Magdalena C; $44.631113^{\circ} \mathrm{S}, 72.929130^{\circ} \mathrm{W}$; depth $15 \mathrm{~m}$; 5-10 Aug. 2016; Marco Bertolino leg.; on a rocky wall by scuba diving; CILE 100; MSGN 61500.

\section{Description}

HABITUS. Encrusting sponge about $5 \mathrm{~cm}$ long and $1.5 \mathrm{~cm}$ thick, with regular conulose surface. Colour in life bright yellow (Fig. 15A). Live specimens soft, very fragile, showing numerous oscula with low rim (Fig. 15A). Ostia also visible on sponge surface (Fig. 15A)

SkELETon. Structure typical of Darwinella genus with ascending dendritic fibres supporting surface conules. Several dendritic fibres arise from common basal plate. Red dendritic fibres laminated, linear and sinuous, 14-(15)-16 mm long and 70-(80)-90 $\mu \mathrm{m}$ thick, with opaque core (Fig. 15B); axial core 10-(11)-12 $\mu \mathrm{m}$ thick. 


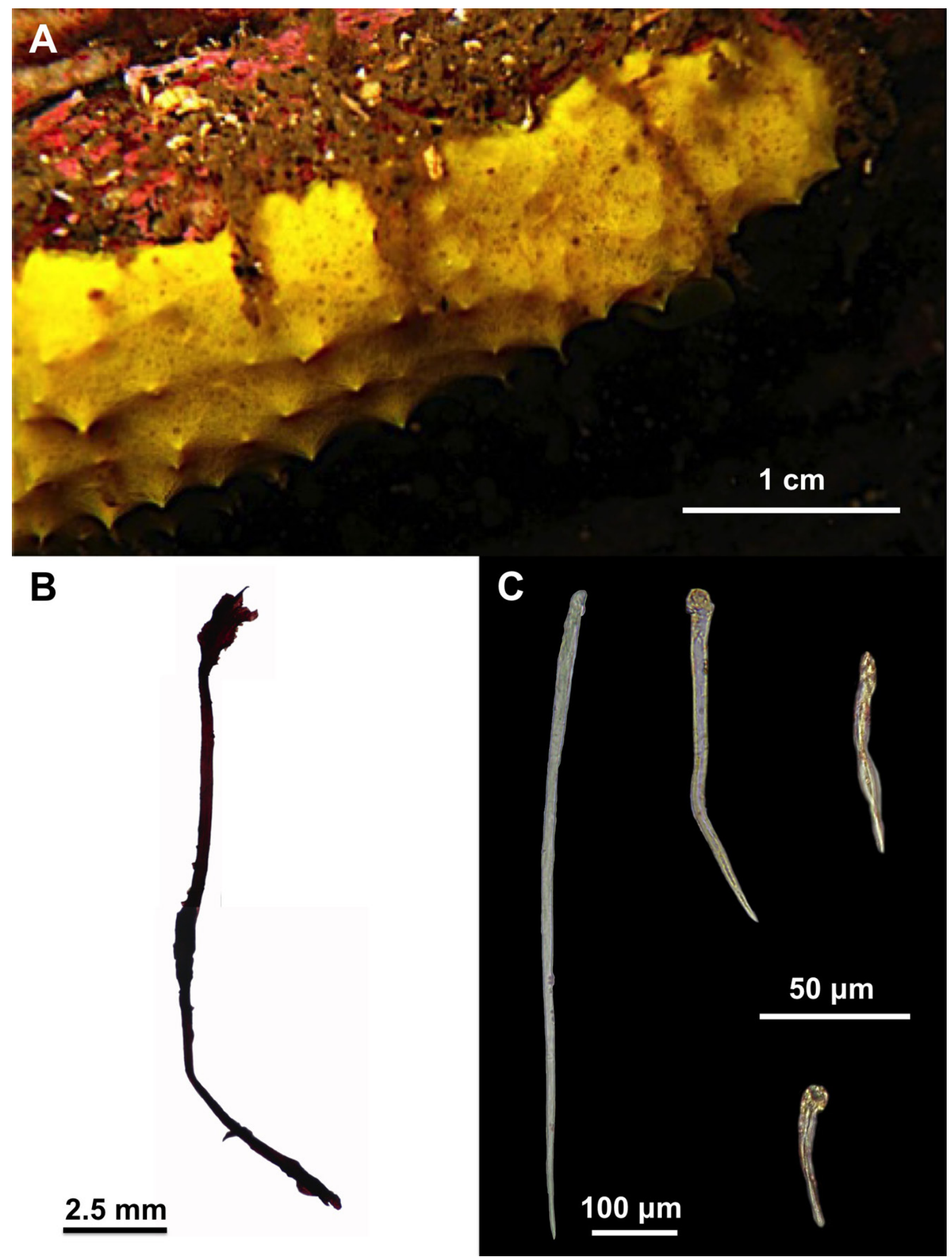

Fig. 15. Darwinella pronzatoi Bertolino, Costa \& Pansini sp. nov., holotype (CILE 100; MSGN 61500). A. The holotype in life. B. Dendritic fibres. C. Horny styles 
SPICULES. Smooth, straight, slightly curved or sinuous horny styles, with visible axial core (Fig. 15C), 87.5-(436)-830 $\mu \mathrm{m}$ long and 9-(12.5)-16 $\mu \mathrm{m}$ thick; axial core 2.5-(8.3)-13 $\mu \mathrm{m}$ thick.

\section{Habitat}

Species lives at a depth of $15 \mathrm{~m}$ in a shady area on rocky wall.

\section{Remarks}

Up to now, there was no evidence of the presence of the genus Darwinella from the Chilean coasts. Thirteen species belonging to this genus have been described worldwide, eleven of which have multiradiate spicules and one species, Darwinella tango (Poiner \& Taylor, 1990), has no spicules. Only two species are characterized by monaxonic spicules: $D$. gardineri Topsent, 1905, characterised by curved horny oxeas $(1600-2000 \times 20 \mu \mathrm{m})$, and $D$. oxeata Bergquist, 1961, having horny spined oxeas (530$2083 \times 4.2-29.8 \mu \mathrm{m})$. Due to the presence of smooth, straight, slightly curved or sinuous horny styles, D. pronzatoi is clearly different from both these species, therefore it should be considered as a species new to science.

\section{Discussion}

With 23 identified species the present study notably increases the number of sponges reported from Chilean fjords to 139 (Table 8).

From a biogeographic standpoint, apart from the nine new species, one species, Biemna lutea Bertolino, Costa \& Pansini, 2019, is recorded for the first time after its description in the same region; 12 species were already recorded from the Chilean coast; and one species, Hymedesmia (Stylopus) lissostyla described from New Zealand, is recorded for the first time in the Chilean sponge fauna (Table 2).

Taking into account the literature together with our data, the total number of sponge species known along the Chilean coasts, increases to 187 (Table 8).

The sponge fauna of the fjord region is strongly separated from that recorded in the other areas of the Chilean coasts. In fact, among the 139 species described for the fjords and the 73 listed for the Chilean coasts, only 25 are in common. This number clearly shows the peculiarity of the Southern Chilean coast and suggests the necessity of a further effort to achieve a satisfactory knowledge of the biodiversity of this area. 
Table 8 (continued on the next five pages). List of sponge species hitherto recorded for the whole Chilean coast.

\begin{tabular}{|c|c|c|c|}
\hline & & $\begin{array}{c}\text { Inside the } \\
\text { fjords }\end{array}$ & $\begin{array}{c}\text { Outside } \\
\text { the fjords }\end{array}$ \\
\hline Class & Calcarea Bowerbank, 1864 & & \\
\hline Subclass & Calcaronea Bibber, 1898 & & \\
\hline \multirow[t]{11}{*}{ Order } & Leucosolenida Hartman, 1958 & & \\
\hline & Sycettusa chilensis Azevedo, Hajdu, Willenz \& Klautau, 2009 & + & + \\
\hline & Vosmaeropsis sericata (Ridley, 1881) & + & \\
\hline & Leucosolenia australis Brøndsted, 1931 & + & \\
\hline & Leucosolenia lucasi Dendy, 1891 & + & \\
\hline & Leucandra fernandensis (Breitfuss, 1898) & & + \\
\hline & Leucandra masatierrae (Breitfuss, 1898) & & + \\
\hline & Leucandra platei (Breitfuss, 1898) & + & \\
\hline & Sycon huinayense Azevedo, Hajdu, Willenz \& Klautau, 2009 & + & \\
\hline & Sycon incrustans Breitfuss, 1898 & + & + \\
\hline & Sycon proboscideum sensu Breitfuss, 1898 & + & + \\
\hline Subclass & Calcinea Bibber, 1898 & & \\
\hline \multirow[t]{7}{*}{ Order } & Clathrinida Hartman, 1958 & & \\
\hline & Clathrina antofagastensis Azevedo, Hajdu, Willenz \& Klautau, 2009 & & + \\
\hline & Clathrina fjordica Azevedo, Hajdu, Willenz \& Klautau, 2009 & + & \\
\hline & Clathrina primordialis (Haeckel, 1872)? & $\begin{array}{l}\text { Doubt } \\
\text { presence }\end{array}$ & \\
\hline & Clathrina ramosa (Azevedo, Hajdu, Willenz \& Klautau, 2009) & + & \\
\hline & Leucettusa nuda (Azevedo, Hajdu, Willenz \& Klautau, 2009) & + & + \\
\hline & Ascaltis poterium (Haeckel, 1872) & + & \\
\hline Class & Demospongiae Sollas, 1885 & & \\
\hline Subclass & Heteroscleromorpha Cárdenas, Pérez \& Boury-Esnault, 2012 & & \\
\hline \multirow[t]{2}{*}{ Order } & Agelasida Hartman, 1980 & & \\
\hline & Hymerhabdia imperfecta Bertolino, Costa \& Pansini sp. nov. & + & \\
\hline \multirow[t]{7}{*}{ Order } & Axinellida Lévi, 1953 & & \\
\hline & Axinella antarctica (Koltun, 1964) & + & \\
\hline & Axinella coronata Bertolino, Costa \& Pansini sp. nov. & + & \\
\hline & Axinella crinita Thiele, 1905 & + & + \\
\hline & Axinella cylindrica Bertolino, Costa \& Pansini sp. nov. & + & \\
\hline & Dragmacidon egregium (Ridley, 1881) & + & \\
\hline & Phakellia sur Carvalho, Desqueyroux-Faúndez \& Hajdu, 2007 & + & \\
\hline \multirow[t]{6}{*}{ Order } & Bubarida Morrow \& Cárdenas, 2015 & & \\
\hline & Bubaris murrayi Topsent, 1913 & + & \\
\hline & Bubaris vermiculata (Bowerbank, 1866)? & $\begin{array}{l}\text { Doubt } \\
\text { presence }\end{array}$ & \\
\hline & Acanthella danerii Costa, Bavestrello, Pansini \& Bertolino, 2020 & + & \\
\hline & Eurypon miniaceum Thiele, 1905 & + & \\
\hline & Halicnemia papillosa (Thiele, 1905) & + & \\
\hline \multirow[t]{7}{*}{ Order } & Biemnida Morrow, 2013 & & \\
\hline & Biemna aurantiaca Bertolino, Costa \& Pansini sp. nov. & + & \\
\hline & Biemna chilensis Thiele, 1905 & + & \\
\hline & Biemna erecta Bertolino, Costa \& Pansini sp. nov. & + & \\
\hline & Biemna lutea Bertolino, Costa \& Pansini, 2019 & + & \\
\hline & Biemna typica Bertolino, Costa \& Pansini sp. nov. & + & \\
\hline & Rhabderemia uruguaiensis van Soest \& Hooper, 1993 & + & \\
\hline
\end{tabular}


Table 8 (continued). List of sponge species hitherto recorded for the whole Chilean coast.

\begin{tabular}{|c|c|c|c|}
\hline & & $\begin{array}{l}\text { Inside the } \\
\text { fjords }\end{array}$ & $\begin{array}{l}\text { Outside } \\
\text { the fjords }\end{array}$ \\
\hline \multirow[t]{5}{*}{ Order } & Clionaida Morrow \& Cárdenas, 2015 & & \\
\hline & Cliona chilensis Thiele, 1905 & + & \\
\hline & Clionaopsis platei (Thiele, 1905) & + & + \\
\hline & Cliothosa hancocki (Topsent, 1888)? & $\begin{array}{c}\text { Doubt } \\
\text { presence }\end{array}$ & \\
\hline & Spheciospongia vesparium (Lamarck, 1815)? & $\begin{array}{c}\text { Doubt } \\
\text { presence }\end{array}$ & \\
\hline \multirow[t]{2}{*}{ Order } & Desmacellida Morrow \& Cárdenas, 2015 & & \\
\hline & Desmacella vestibularis (Wilson, 1904) & & + \\
\hline \multirow[t]{31}{*}{ Order } & Haplosclerida Topsent, 1928 & & \\
\hline & Callyspongia fusifera (Thiele, 1905) & + & + \\
\hline & Siphonochalina fortis Ridley, 1881 & + & \\
\hline & Chalinula variabilis (Thiele, 1905) & + & \\
\hline & Haliclona (Halichoclona) conica (Thiele, 1905) & + & \\
\hline & $\begin{array}{l}\text { Haliclona (Reniera) caduca Hajdu, Desqueyroux-Faúndez, Carvalho, } \\
\text { Lôbo-Hajdu \& Willenz, } 2013\end{array}$ & + & \\
\hline & Haliclona (Reniera) delicata (Sarà, 1978) & + & \\
\hline & Haliclona (Reniera) infundibularis (Ridley \& Dendy, 1887) & + & \\
\hline & Haliclona (Reniera) topsenti $($ Thiele, 1905$)$ & + & \\
\hline & Haliclona (Rhizoniera) anceps (Thiele, 1905) & & + \\
\hline & Haliclona (Soestella) auletta (Thiele, 1905) & + & \\
\hline & Haliclona (Soestella) chilensis (Thiele, 1905) & + & + \\
\hline & Haliclona algicola (Thiele, 1905) & + & \\
\hline & Haliclona bilamellata Burton, 1932 & + & \\
\hline & Haliclona ignobilis (Thiele, 1905) & + & + \\
\hline & Haliclona inepta (Thiele, 1905) & + & \\
\hline & Haliclona macropora (Thiele, 1905) & + & + \\
\hline & Haliclona nodosa (Thiele, 1905) & + & \\
\hline & Haliclona rugosa (Thiele, 1905) & + & \\
\hline & Haliclona siphonella (Thiele, 1905) & + & \\
\hline & Haliclona sordida (Thiele, 1905) & + & \\
\hline & Haliclona spinosella $($ Thiele, 1905) & + & \\
\hline & Haliclona thielei van Soest \& Hooper, 2020 & & + \\
\hline & Haliclona verrucosa $($ Thiele, 1905$)$ & + & \\
\hline & Haliclona virens (Topsent, 1908) & + & \\
\hline & Amphimedon decurtata (Sarà, 1978) & + & \\
\hline & Amphimedon maresi (Sarà, 1978) & + & \\
\hline & Amphimedon reticulosa (Thiele, 1905) & + & \\
\hline & Dasychalina magellanica (Thiele, 1905) & + & \\
\hline & Dasychalina validissima (Thiele, 1905) & + & \\
\hline & Pachychalina tenera Thiele, 1905 & + & \\
\hline
\end{tabular}


Table 8 (continued). List of sponge species hitherto recorded for the whole Chilean coast. * = new record for Chile.

\begin{tabular}{|c|c|c|c|}
\hline & & $\begin{array}{l}\text { Inside the } \\
\text { fjords }\end{array}$ & $\begin{array}{l}\text { Outside } \\
\text { the fjords }\end{array}$ \\
\hline & $\begin{array}{l}\text { Oceanapia guaiteca Hajdu, Desqueyroux-Faúndez, Carvalho, Lôbo-Hajdu } \\
\& \text { Willenz, } 2013\end{array}$ & + & \\
\hline & $\begin{array}{l}\text { Oceanapia spinisphaera Hajdu, Desqueyroux-Faúndez, Carvalho, } \\
\text { Lôbo-Hajdu \& Willenz, } 2013\end{array}$ & + & \\
\hline \multirow[t]{33}{*}{ Order } & Poecilosclerida Topsent, 1928 & & \\
\hline & Iophon proximum (Ridley, 1881) & + & + \\
\hline & Iophon radiatum Topsent, 1901 & & + \\
\hline & Iophon timidum Desqueyroux-Faúndez \& van Soest, 1996 & + & \\
\hline & Iophon tubiforme Desqueyroux-Faúndez \& van Soest, 1996 & + & \\
\hline & Iophon unicorne Topsent, 1907 & + & \\
\hline & Forcepia (Leptolabis) irritans (Thiele, 1905) & & + \\
\hline & $\begin{array}{l}\text { Lissodendoryx (Ectyodoryx) ballena Fernandez, Cárdenas, Bravo, } \\
\text { Lôbo-Hajdu, Willenz \& Hajdu, } 2016\end{array}$ & + & \\
\hline & $\begin{array}{l}\text { Lissodendoryx (Ectyodoryx) coloanensis Fernandez, Cárdenas, Bravo, } \\
\text { Lôbo-Hajdu, Willenz \& Hajdu, } 2016\end{array}$ & + & \\
\hline & $\begin{array}{l}\text { Lissodendoryx (Ectyodoryx) corrugata Fernandez, Cárdenas, Bravo, } \\
\text { Lôbo-Hajdu, Willenz \& Hajdu, } 2016\end{array}$ & + & \\
\hline & $\begin{array}{l}\text { Lissodendoryx (Ectyodoryx) diegoramirezensis Fernandez, Cárdenas, } \\
\text { Bravo, Lôbo-Hajdu, Willenz \& Hajdu, } 2016\end{array}$ & + & \\
\hline & Lissodendoryx (Ectyodoryx) patagonica (Ridley \& Dendy, 1886) & + & \\
\hline & Batzella mollis Thiele, 1905 & & + \\
\hline & Strongylacidon platei (Thiele, 1905) & & + \\
\hline & Abyssocladia diegoramirezensis Lopes, Bravo \& Hajdu, 2011 & & + \\
\hline & Abyssocladia umbellata Lopes, Bravo \& Hajdu, 2011 & & + \\
\hline & Asbestopluma (Asbestopluma) bitrichela Lopes, Bravo \& Hajdu, 2011 & + & + \\
\hline & Asbestopluma (Asbestopluma) magnifica Lopes, Bravo \& Hajdu, 2011 & + & \\
\hline & Asbestopluma (Helophloeina) delicata Lopes, Bravo \& Hajdu, 2011 & + & \\
\hline & Chondrocladia (Chondrocladia) schlatteri Lopes, Bravo \& Hajdu, 2011 & & + \\
\hline & Chondrocladia (Meliiderma) latrunculioides Lopes, Bravo \& Hajdu, 2011 & & + \\
\hline & Lycopodina microstrongyla (Lopes, Bravo \& Hajdu, 2011) & & + \\
\hline & Crambe amarilla Esteves, Lôbo-Hajdu \& Hajdu, 2007 & + & \\
\hline & Crambe chilensis Esteves, Lôbo-Hajdu \& Hajdu, 2007 & + & \\
\hline & Crambe maldonadoi Esteves, Lôbo-Hajdu \& Hajdu, 2007 & + & \\
\hline & Amphilectus americanus (Ridley \& Dendy, 1887) & + & \\
\hline & Amphilectus fucorum (Esper, 1794)? & $\begin{array}{c}\text { Doubt } \\
\text { presence }\end{array}$ & \\
\hline & Amphilectus rugosus (Thiele, 1905) & + & \\
\hline & Hamigera cleistochela Bertolino, Costa \& Pansini, 2019 & + & \\
\hline & Hymedesmia (Stylopus) lissostyla (Bergquist \& Fromont, 1988) * & + & \\
\hline & Phorbas areolatus (Thiele, 1905) & + & \\
\hline & Isodictya delicata (Thiele, 1905) & + & + \\
\hline & Latrunculia (Latrunculia) basalis Kirkpatrick, 1908 & + & \\
\hline
\end{tabular}


Table 8 (continued). List of sponge species hitherto recorded for the whole Chilean coast.

\begin{tabular}{|c|c|c|}
\hline & $\begin{array}{l}\text { Inside the } \\
\text { fjords }\end{array}$ & $\begin{array}{l}\text { Outside } \\
\text { the fjords }\end{array}$ \\
\hline $\begin{array}{l}\text { Latrunculia (Latrunculia) ciruela Hajdu, Desqueyroux-Faúndez, Carvalho, } \\
\text { Lôbo-Hajdu \& Willenz, } 2013\end{array}$ & + & \\
\hline $\begin{array}{l}\text { Latrunculia (Latrunculia) copihuensis Hajdu, Desqueyroux-Faúndez, } \\
\text { Carvalho, Lôbo-Hajdu \& Willenz, } 2013\end{array}$ & + & \\
\hline $\begin{array}{l}\text { Latrunculia (Latrunculia) yepayek Hajdu, Desqueyroux-Faúndez, Carvalho, } \\
\text { Lôbo-Hajdu \& Willenz, } 2013\end{array}$ & + & \\
\hline $\begin{array}{l}\text { Latrunculia (Latrunculia) verenae Hajdu, Desqueyroux-Faúndez, Carvalho, } \\
\text { Lôbo-Hajdu \& Willenz, } 2013\end{array}$ & + & \\
\hline Antho (Acarnia) inconspicua (Desqueyroux, 1972) & & + \\
\hline Clathria (Clathria) discreta (Thiele, 1905) & + & + \\
\hline Clathria (Clathria) lipochela Burton, 1932 & + & \\
\hline Clathria (Clathria) microxa Desqueyroux, 1972 & + & \\
\hline Clathria (Clathria) papillosa Thiele, 1905 & + & \\
\hline Clathria (Cornulotrocha) polita (Ridley, 1881) & + & + \\
\hline $\begin{array}{l}\text { Clathria (Cornulotrocha) rosetafiordica Hajdu, Desqueyroux-Faúndez \& } \\
\text { Willenz, } 2006\end{array}$ & + & \\
\hline Clathria (Microciona) antarctica (Topsent, 1917) & & + \\
\hline $\begin{array}{l}\text { Clathria (Microciona) mytilifila Hajdu, Desqueyroux-Faúndez, Carvalho, } \\
\text { Lôbo-Hajdu \& Willenz, } 2013\end{array}$ & + & \\
\hline Clathria (Thalysias) amabilis (Thiele, 1905) & + & \\
\hline Clathria (Thalysias) membranacea (Thiele, 1905) & & + \\
\hline Mycale (Aegogropila) magellanica (Ridley, 1881) & + & \\
\hline Mycale (Carmia) gaussiana Hentschel, 1914 & & + \\
\hline Mycale (Mycale) doellojuradoi Burton, 1940 & & + \\
\hline Mycale (Mycale) thielei Hajdu \& Desqueyroux-Faúndez, 1994 & + & \\
\hline Mycale (Mycale) tridens Hentschel, 1914 & + & \\
\hline Mycale (Oxymycale) acerata Kirkpatrick, 1907 ? & $\begin{array}{c}\text { Doubt } \\
\text { presence }\end{array}$ & \\
\hline Hymenancora laevis (Thiele, 1905) & + & + \\
\hline Hymenancora tenuissima (Thiele, 1905) & + & \\
\hline $\begin{array}{l}\text { Myxilla (Burtonanchora) araucana Hajdu, Desqueyroux-Faúndez, } \\
\text { Carvalho, Lôbo-Hajdu \& Willenz, } 2013\end{array}$ & + & \\
\hline Myxilla (Ectyomyxilla) chilensis Thiele, 1905 & + & + \\
\hline Myxilla (Ectyomyxilla) massa Ridley \& Dendy, 1887 & + & \\
\hline Myxilla (Myxilla) mollis Ridley \& Dendy, 1886 & + & \\
\hline Stelodoryx cribrigera (Ridley \& Dendy, 1886) & + & \\
\hline $\begin{array}{l}\text { Neopodospongia tupecomareni Hajdu, Desqueyroux-Faúndez, Carvalho, } \\
\text { Lôbo-Hajdu \& Willenz, } 2013\end{array}$ & + & \\
\hline Tedania (Tedaniopsis) charcoti Topsent, 1907 & + & \\
\hline Tedania (Tedaniopsis) mucosa Thiele, 1905 & + & + \\
\hline Tedania (Tedaniopsis) tenuicapitata Ridley, 1881 & + & \\
\hline Trachytedania patagonica Ridley \& Dendy, 1886 & + & \\
\hline Trachytedania spinata Ridley, 1881 & + & \\
\hline
\end{tabular}


Table 8 (continued). List of sponge species hitherto recorded for the whole Chilean coast.

\begin{tabular}{|c|c|c|c|}
\hline & & $\begin{array}{l}\text { Inside the } \\
\text { fjords }\end{array}$ & $\begin{array}{l}\text { Outside } \\
\text { the fjords }\end{array}$ \\
\hline \multirow[t]{5}{*}{ Order } & Polymastiida Morrow \& Cárdenas, 2015 & & \\
\hline & Polymastia invaginata Kirkpatrick, 1907 & + & \\
\hline & Polymastia isidis Thiele, 1905 & + & \\
\hline & Scopalina bunkeri Goodwin, Jones, Neely \& Brickle, 2011 & + & \\
\hline & Scopalina cribrosa Bertolino, Costa \& Pansini sp. nov. & + & \\
\hline \multirow[t]{18}{*}{ Order } & Suberitida Chombard \& Boury-Esnault, 1999 & & \\
\hline & Halichondria (Halichondria) prostrata Thiele, 1905 & & + \\
\hline & Hymeniacidon calva (Ridley, 1881) & + & + \\
\hline & Hymeniacidon corticata (Thiele, 1905) & + & + \\
\hline & Hymeniacidon fernandezi Thiele, 1905 & & + \\
\hline & Hymeniacidon longistylus Desqueyroux, 1972 & + & \\
\hline & Hymeniacidon rubiginosa Thiele, 1905 & & + \\
\hline & Johannesia reticulosa (Thiele, 1905) & & + \\
\hline & Plicatellopsis expansa (Thiele, 1905) & & + \\
\hline & Plicatellopsis flabellata Burton, 1932 & + & \\
\hline & Protosuberites epiphytoides (Thiele, 1905) & & + \\
\hline & Pseudosuberites digitatus (Thiele, 1905) & + & + \\
\hline & Pseudosuberites hyalinus (Ridley \& Dendy, 1887) & + & + \\
\hline & Pseudosuberites sulcatus (Thiele, 1905) & + & + \\
\hline & Rhizaxinella strongylata Bertolino, Costa \& Pansini sp. nov. & + & \\
\hline & $\begin{array}{l}\text { Suberites cranium Hajdu, Desqueyroux-Faúndez, Carvalho, Lôbo-Hajdu \& } \\
\text { Willenz, } 2013\end{array}$ & + & \\
\hline & Suberites puncturatus Thiele, 1905 & & + \\
\hline & Suberites ruber Thiele, 1905 & + & + \\
\hline \multirow[t]{4}{*}{ Order } & Tethyda Morrow \& Cárdenas, 2015 & & \\
\hline & $\begin{array}{l}\text { Tethya melinka Hajdu, Desqueyroux-Faúndez, Carvalho, Lôbo-Hajdu \& } \\
\text { Willenz, } 2013\end{array}$ & + & \\
\hline & Tethya papillosa (Thiele, 1905) & & + \\
\hline & Timea authia de Laubenfels, 1930 & & + \\
\hline \multirow[t]{4}{*}{ Order } & Tetractinellida Marshall, 1876 & & \\
\hline & Stelletta clarella de Laubenfels, 1930 & + & \\
\hline & Stelletta phrissens Sollas, 1886 & + & \\
\hline & Geodia magellani (Sollas, 1886) & + & \\
\hline Subclass & Keratosa Grant, 1861 & & \\
\hline \multirow[t]{5}{*}{ Order } & Dendroceratida Minchin, 1900 & & \\
\hline & Aplysilla lendenfeldi Thiele, 1905 & & + \\
\hline & Darwinella pronzatoi Bertolino, Costa \& Pansini sp. nov. & + & \\
\hline & Spongionella regularis (Ridley, 1881) & + & \\
\hline & Spongionella repens (Thiele, 1905) & & + \\
\hline \multirow[t]{2}{*}{ Order } & Dictyoceratida Minchin, 1900 & & \\
\hline & Dysidea chilensis (Thiele, 1905) & + & \\
\hline
\end{tabular}


Table 8 (continued). List of sponge species hitherto recorded for the whole Chilean coast.

\begin{tabular}{|c|c|c|c|}
\hline & & $\begin{array}{l}\text { Inside the } \\
\text { fjords }\end{array}$ & $\begin{array}{c}\text { Outside } \\
\text { the fjords }\end{array}$ \\
\hline & Ircinia clavata (Thiele, 1905) & & + \\
\hline & Ircinia paupera $($ Thiele, 1905$)$ & & + \\
\hline & Ircinia variabilis (Schmidt, 1862)? & $\begin{array}{c}\text { Doubt } \\
\text { presence }\end{array}$ & \\
\hline & Spongia (Spongia) cerebralis Thiele, 1905 & & + \\
\hline & Spongia (Spongia) magellanica Thiele, 1905 & + & + \\
\hline & Hyrtios arenosus (Thiele, 1905) & & + \\
\hline & Hyrtios sororia (Thiele, 1905) & & + \\
\hline & Scalarispongia similis (Thiele, 1905) & & + \\
\hline Subclass & $\begin{array}{l}\text { Verongimorpha Erpenbeck, Sutcliffe, Cook, Dietzel, Maldonado, van } \\
\text { Soest, Hooper \& Wörheide, } 2012\end{array}$ & & \\
\hline \multirow[t]{3}{*}{ Order } & $\begin{array}{l}\text { Chondrillida Redmond, Morrow, Thacker, Díaz, Boury-Esnault, } \\
\text { Cárdenas, Hajdu, Lôbo-Hajdu, Picton, Pomponi, Kayal \& Collins, } 2013\end{array}$ & & \\
\hline & Halisarca desqueyrouxae Willenz, Ereskovsky \& Lavrov, 2016 & + & \\
\hline & Halisarca magellanica Topsent, 1901 & + & \\
\hline Class & Hexactinellida Schmidt, 1870 & & \\
\hline Subclass & Amphidiscophora Schulze, 1886 & & \\
\hline \multirow[t]{5}{*}{ Order } & Amphidiscosida Schrammen, 1924 & & \\
\hline & Hyalonema (Corynonema) grandancora Lendenfeld, 1915 & & + \\
\hline & Hyalonema (Prionema) poculum Schulze, 1886 & & + \\
\hline & Pheronema nasckaniense Tabachnick, 1990 & & + \\
\hline & Schulzeviella gigas (Schulze, 1886) & & + \\
\hline Subclass & Hexasterophora Schulze, 1886 & & \\
\hline \multirow[t]{11}{*}{ Order } & Lyssacinosida Zittel, 1877 & & \\
\hline & Pseudoplectella dentatum Tabachnick, 1990 & & + \\
\hline & Regadrella phoenix Schmidt, 1880 & & + \\
\hline & Staurocalyptus roeperi (Schulze, 1886) & + & \\
\hline & Caulophacus (Caulophacus) chilensis Reiswig \& Araya, 2014 & & + \\
\hline & Lanugonychia flabellum Lendenfeld, 1915 & & + \\
\hline & Aphorme horrida Schulze, 1899 & & + \\
\hline & Hyalascus stellatus (Schulze, 1886) & + & \\
\hline & Rossella antarctica Carter, 1872 & + & \\
\hline & Rossella racovitzae Topsent, 1901 & & + \\
\hline & Scyphidium chilense Ijima, 1927 & + & \\
\hline Subclass & Hexasterophora Schulze, 1886 & & \\
\hline \multirow[t]{2}{*}{ Order } & Sceptrulophora Mehl, 1992 & & \\
\hline & Pararete farreopsis (Carter, 1877) & & + \\
\hline Class & Homoscleromorpha Bergquist, 1978 & & \\
\hline \multirow[t]{2}{*}{ Order } & Homosclerophorida Bergquist, 1978 & & \\
\hline & Plakina trilopha Schulze, 1880 ? & $\begin{array}{l}\text { Doubt } \\
\text { presence }\end{array}$ & \\
\hline Total & 187 species +8 doubt presence & 139 & 73 \\
\hline
\end{tabular}




\section{Acknowledgements}

Partial funding from COPAS Sur Austral Program grant \# PFB-31. We are indebted to Dr. David Crawford for his useful suggestions regarding the English language.

\section{References}

Azevedo F., Hajdu E., Willenz P. \& Klautau M. 2009. New records of Calcareous sponges (Porifera, Calcarea) from the Chilean coast. Zootaxa 2072 (1): 1-30. https://doi.org/10.11646/zootaxa.2072.1.1

Bertolino M., Costa G., Reboa A., Bavestrello G., Pansini M., Betti F., Marzia Bo. \& Daneri G. 2019. The sponge fauna of the Seno Magdalena and Puyuhuapi Fjord (Chile), with a description of two new species. Zootaxa 4623 (2): 306-320. https://doi.org/10.11646/zootaxa.4623.2.5

Carvalho M.S., Desqueyroux-Faúndez R. \& Hajdu E. 2007. Phakellia sur sp. nov. (Demospongiae, Halichondrida, Axinellidae) from the lower slope off Cape Horn (South America), with a revision of the genus. Marine Biology Research 3 (2): 109-116. https://doi.org/10.1080/17451000701276063

Carvalho M.S., Desqueyroux-Faúndez R. \& Hajdu E. 2011. Taxonomic notes on Poecillastra sponges (Astrophorida: Pachastrellidae), with the description of three new bathyal southeastern Pacific species. Scientia Marina 75 (3): 477-492. https://doi.org/10.3989/scimar.2011.75n3477

Costa G., Bavestrello G., Pansini M. \& Bertolino M. 2020. Acanthella danerii sp. nov. (Demospongiae, Bubarida, Dictyonellidae) from Chilean fjords (South Pacific Ocean). Zootaxa 4790 (2): 393-396. https://doi.org/10.11646/zootaxa.4790.2.13

Desqueyroux R. 1972. Demospongiae (Porifera) de la Costa de Chile. Gayana 20: 3-71.

Desqueyroux R. \& Moyano H. 1987. Zoogeografía de demospongias chilenas. Boletín de la Sociedad de Biología de Concepción (Chile) 58: 39-66.

Escribano R., Fernández M. \& Aranís A. 2003. Physical-chemical processesand patterns of diversity of the Chilean eastern boundary pelagic and benthic marine ecosystems: an overview. Gayana 67: 190-205. https://doi.org/10.4067/S0717-65382003000200008

Esteves E.L., Lôbo-Hajdu G. \& Hajdu E. 2007. Three new species of Crambe (Crambeidae: Poecilosclerida: Demospongiae) from the south-eastern Pacific, with a review of morphological characters for the genus. Journal of the Marine Biological Association of the United Kingdom 87: 13671378. https://doi.org/10.1017/S0025315407058110

Fernandez J.C., Cárdenas C.A., Bravo A., Lôbo-Hajdu G., Willenz P. \& Hajdu E. 2016. Lissodendoryx (Ectyodoryx) Lundbeck, 1909 (Coelosphaeridae, Poecilosclerida, Demospongiae) from Southern Chile: new species and a discussion of morphologic characters in the subgenus. Zootaxa 4092 (1): 69-89. https://doi.org/10.11646/zootaxa.4092.1.4

Försterra G. 2009. Ecological and biogeographical aspects of the Chilean fjord region. In: Häussermann V. \& Försterra G. (eds) Marine Benthic Fauna of Chilean Patagonia: 61-76. Nature in Focus, Santiago de Chile.

Försterra G. \& Häussermann V. 2003. First report on large scleractinian (Cnidaria: Anthozoa) accumulations in cold-temperate shallow water of south Chilean fjords. Zoologische Verhandelingen 345: $117-128$.

Hajdu E. \& Desqueyroux-Faúndez R. 2008. A reassessment of the phylogeny and biogeography of Rhabderemia Topsent, 1890 (Rhabderemiidae, Poecilosclerida, Demospongiae). Revue suisse de Zoologie 115 (2): 377-395. 
Hajdu E., Desqueyroux-Faúndez R. \& Willenz P. 2006. Clathria (Cornulotrocha) rosetafiordica sp. nov. from a south-east Pacifc fjord (Chilean Patagonia) (Microcionidae: Poecilosclerida: Demospongiae: Porifera). Journal of the Marine Biological Association of United Kingdom 86: 957-961.

https://doi.org/10.1017/S0025315406013920

Hajdu E., Desqueyroux-Faúndez R., Carvalho M. de S., Lôbo-Hajdu G. \& Willenz P. 2013. Twelve new Demospongiae (Porifera) from Chilean fjords, with remarks upon sponge-derived biogeographic compartments in the SE Pacific. Zootaxa 3744: 1-64. https://doi.org/10.11646/zootaxa.3744.1.1

Häussermann V. 2006. Biodiversity of Chilean sea anemones (Cnidaria: Anthozoa): distribution patterns and zoogeographic implications, including new records for the fjord region. Investigation Marine 34 (2): 23-35. https://doi.org/10.4067/S0717-71782006000200003

Häussermann V. \& Försterra G. 2007a. Extraordinary abundance of hydrocorals (Cnidaria, Hydrozoa, Stylasteridae) in shallow water of the Patagonian fjord region. Polar Biology 30: 487-492.

https://doi.org/10.1007/s00300-006-0207-5

Häussermann V. \& Försterra G. 2007b. Large assemblages of cold-water corals in Chile: a summary of recent findings and potential impacts. Bullettin of Marine Sciencie 81(Suppl. 1): 195-207.

Häussermann V. \& Försterra G. 2009. Marine Benthic Fauna of Chilean Patagonia. Nature in Focus, Santiago de Chile.

Iriarte J.L., Pantoja S. \& Daneri G. 2014. Oceanographic processes in Chilean fjords of Patagonia; from small to large scale studies. Progress in Oceanography 129: 1-7.

https://doi.org/10.1016/j.pocean.2014.10.004

Lee M.R., Castilla J.C., Fernandez M., Clarke M., Gonzalez C., Hermosilla C., Prado L., Rozbaczylo N. \& Valdovinos C. 2008. Free-living benthic marine invertebrates in Chile. Revista Chilena de Historia Natural 81: 51-67. https://doi.org/10.4067/S0716-078X2008000100005

Lopes D.A., Bravo A. \& Hajdu E. 2011. New carnivorous sponges (Cladorhizidae: Poecilosclerida: Demospongiae) from off Diego Ramírez Archipelago (south Chile), with comments on taxonomy and biogeography of the family. Invertebrate Systematics 25 (5): 407-443. https://doi.org/10.1071/IS11015

Morrow C. \& Cárdenas P. 2015. Proposal for a revised classification of the Demospongiae (Porifera). Frontiers in Zoology 12 (1): 7. https://doi.org/10.1186/s12983-015-0099-8

Müller F. 1865. Uber Darwinella aurea, einen Schwamm mit sternförmigen Hornnadeln. Archiv für mikroskopische Anatomie und Entwicklungsmechanik 1: 344-353.

Pantoja S., Iriarte J.L. \& Daneri G. 2011. Oceanography of the Chilean Patagonia. Continental Shelf Research 31: 149-153. https://doi.org/10.1016/j.csr.2010.10.013

Pronzato R. 1975. Note tassonomiche sul genere Darwinella (Porifera). Bollettino dei Musei e degli Istituti Biologici dell'Università di Genova 43: 5-20.

Ridley S.O. 1881. XI. Spongida. Horny and siliceous sponges of Magellan Straits, S.W. Chili, and Atlantic off S.W. Brazil. In: Gunther A. (ed.) Account of the Zoological Collections made during the Survey of H.M.S. 'Alert' in the Straits of Magellan and on the Coast of Patagonia (1881): 107-137, 140-141. Proceedings of the Zoological Society of London 1881.

https://doi.org/10.1111/j.1096-3642.1881.tb01270.x

Ridley S.O. \& Dendy A. 1887. Report on the Monaxonida collected by H.M.S. "Challenger" during the years 1873-76. Report on the Scientific Results of the Voyage of H.M.S. "Challenger" during the years 1873-76. Zoology 20 (59): i-lxviii, 1-275. https://doi.org/10.5962/bhl.title.6513 
Rützler K. 1978. Sponges in coral reefs. In: Stoddart D.R. \& Johannes R.E. (eds) Coral Reefs: Research Methods: 299-313. Monographs on Oceanographic Methodology 5, Unesco, Paris.

Sinniger F. \& Häussermann V. 2009. Zoanthids (Cnidaria: Hexacorallia: Zoantharia) from shallow waters of the southern Chilean fjord region, with descriptions of a new genus and two new species. Organism Diversity \& Evolution 9: 23-36. https://doi.org/10.1016/j.ode.2008.10.003

Thiele J. 1905. Die Kiesel- und Hornschwämme der Sammlung Plate. Zoologische Jahrbücher Suppl. 6 (Fauna Chiliensis III): 407-496, 427-433.

Topsent E. 1901. Spongiaires. Résultats du voyage du S.Y. Belgica en 1897-99 sous le commandement de A. de Gerlache de Gomery. Expédition antarctique belge. Zoologie 4: 1-54.

Topsent E. 1934. Eponges observées dans les parages de Monaco. (Première partie). Bulletin de l'Institut océanographique, Monaco 650: 1-42.

van Soest R.W.M., Boury-Esnault N., Hooper J.N.A., Rützler K., de Voogd N.J., Alvarez B., Hajdu E., Pisera A.B., Manconi R., Schönberg C., Klautau M., Picton B., Kelly M., Vacelet J., Dohrmann M., Díaz M.C., Cárdenas P., Carballo J.L., Rios P., Downey R. \& Morrow C.C. 2020. The World Porifera Database. Available from http://www.marinespecies.org/porifera [accessed 3 Aug. 2020].

Willenz P., Hajdu E., Desqueyroux-Faúndez R., Lôbo-Hajdu G. \& Carvalho M.S. 2009. Class Demospongiae. In: Häussermann V. \& Försterra G. (eds) Marine Benthic Fauna of Chilean Patagonia: 107-157. Nature in Focus, Santiago de Chile.

Willenz P., Alexander V., Ereskovsky A.V., Dennis V. \& Lavrov D.V. 2016. Integrative taxonomic re-description of Halisarca magellanica and description of a new species of Halisarca (Porifera, Demospongiae) from Chilean Patagonia. Zootaxa 4208 (6): 501-533.

https://doi.org/10.11646/zootaxa.4208.6.1

Manuscript received: 12 February 2020

Manuscript accepted: 14 July 2020

Published on: 10 September 2020

Topic editor: Rudy C.A.M. Jocqué

Desk editor: Radka Rosenbaumová

Printed versions of all papers are also deposited in the libraries of the institutes that are members of the EJT consortium: Muséum national d'histoire naturelle, Paris, France; Meise Botanic Garden, Belgium; Royal Museum for Central Africa, Tervuren, Belgium; Royal Belgian Institute of Natural Sciences, Brussels, Belgium; Natural History Museum of Denmark, Copenhagen, Denmark; Naturalis Biodiversity Center, Leiden, the Netherlands; Museo Nacional de Ciencias Naturales-CSIC, Madrid, Spain; Real Jardín Botánico de Madrid CSIC, Spain; Zoological Research Museum Alexander Koenig, Bonn, Germany; National Museum, Prague, Czech Republic. 